Summer 2013

\title{
A Sociology of Constituent Power: The Political Code of Transnational Societal Constitutions
}

Christopher Thornhill

University of Manchester, christopher.thornhill@manchester.ac.uk

Follow this and additional works at: https://www.repository.law.indiana.edu/ijgls

Part of the Constitutional Law Commons, International Law Commons, and the Transnational Law

\section{Commons}

\section{Recommended Citation}

Thornhill, Christopher (2013) "A Sociology of Constituent Power: The Political Code of Transnational Societal Constitutions," Indiana Journal of Global Legal Studies: Vol. 20 : Iss. 2 , Article 3.

Available at: https://www.repository.law.indiana.edu/ijgls/vol20/iss2/3

This Symposium is brought to you for free and open access by the Law School Journals at Digital Repository @ Maurer Law. It has been accepted for inclusion in Indiana Journal of Global Legal Studies by an authorized editor of Digital Repository @ Maurer Law. For more information, please contact rvaughan@indiana.edu.

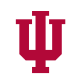

JEROME HALL LAW LIBRARY

INDIANA UNIVERSITY

Maurer School of Law
Blooming ton 


\title{
A Sociology of Constituent Power: The Political Code of Transnational Societal Constitutions
}

\author{
CHRISTOPHER THORNHILL*
}

\begin{abstract}
This article proceeds from a critical sociological revision of classical constitutional theory. In particular, it argues for a sociological reconstruction of the central concepts of constitutional theory: constituent power and rights. These concepts, it is proposed, first evolved as an internal reflexive dimension of the modern political system, which acted originally to stabilize the political system as a relatively autonomous aggregate of actors, adapted to the differentiated interfaces of a modern society.

This revision of classical constitutional theory provides a basis for a distinctive account of transnational constitutional pluralism or societal constitutionalism. The article argues that the construction of transnational normative orders needs to be placed, in a sociological dimension, on a clearer continuum with classical constitutional models. Although contemporary society is marked by multiple, nationally overarching, and often functionally specific constitutions, such normative structures extend the original functions of constituent power and rights.

The article sets out the concluding hypothesis that rights form a running constitution in contemporary society, facilitating highly improbable acts of transnational structural construction and systemic inclusion. It is around the code rights-relevant/rights-irrelevant that transnational society constructs its processes of politicization and political inclusion. This code, however, brings to light a subsidiary or skeletal coding, which was latently co-implied in the political exchanges of modern society, and which was already expressed in early constitutionalism.
\end{abstract}

* Until September 2013, Professor of Politics, University of Glasgow; from September 2013, Professor of Law, University of Manchester.

Indiana Journal of Global Legal Studies Vol. 20, Issue 2 (2013)

(C) Indiana University Maurer School of Law 


\section{INTRODUCTION}

In the last decade, it has become clearly visible that certain distinctive patterns of legal norm formation are developing, in which inter- and transnational laws assume effective constitutional status across former national/territorial boundaries, such that in many respects national constitutions are displaced by, or at least in part incorporated within, a transnational constitutional order. ${ }^{1}$ This emerging constitutional order has been observed from many standpoints. Analysis of the new constitutionality ranges, at one extreme, from an (in itself varied) body of literature embracing the global legal system as a Kantian world constitution based in obligatory human rights to, at the other extreme, literature denying the presence of anything but jurisdictional pluralism in the legal order of modern society. ${ }^{2}$ Inquiry into these phenomena includes both literature fraught

1. Earlier versions of this article were presented twice in April 2012; first at a seminar held at Universidad Adolfo Ibáñez (Santiago de Chile), and then at the conference 'Transnational Societal Constitutionalism' hosted by International University College of Turin (IUC) and Collegio Carlo Alberto (Turin). I wish to record my thanks to the organizers of, and the participants in, both events. Particular gratitude is due to Fernando Atria, Aldo Mascareño, Poul Kjaer, Anna Beckers, and Gunther Teubner, whose questions I have endeavoured to address, either directly or more obliquely, in preparing the final text of this article. As it approached completion, this article also drew much benefit from my discussions with Atina Krajewska.

2. In the former category see HAUKE BRUNKHORST, SOLIDARITÄT: VON DER BÜRgERFREUNDSCHAFT ZUR GLOBALEN RECHTSGENOSSENSCHAFT [SOLIDARITY: FROM Civic FRIENDSHIP TO A GLOBAL LEGAL COMMUNITY] (Ger.) (reconstructing the concept of solidarity in terms of the "history of ideas" and analyzing its connection with the concept of Democracy); Jürgen Habermas, Konstitutionalisierung des Völkerrechts und die Legitimationsprobleme einer verfassten Weltgesellschaft [Constitutionalization of International Law and the Problems of Legitimacy of a Constituted Global Society], in RECHTSPHILOSOPHIE IM 21. JAHRHUNDERT [LEGAL PHILOSOPHY IN THE 21sT CENTURY] 369 (Winfried Brugger, Ulfrid Neumann \& Stephan Kirste eds., 2008) (Ger.) (discussing the idea of a political constitution for a world society and potential legitimacy requirements of a democratically cosntituted world society that lacks a world government); OTFRIED HöfFe, Demokratie Im Zeitalter Der Globalisierung [Democracy IN The AGe of GLOBALIZATION] (1999) (Ger.) (analyzing the term and the dynamics of globalization, highlighting concrete and theoretical problems). On the rise of this perception, see Bardo Fassbender, The Meaning of International Constitutional Law, in TRANSNATIONAL CONSTITUTIONALISM: INTERNATIONAL AND EUROPEAN MODELS 307, 309 (Nicholas Tsagourias ed., 2007). Against these approaches, see Ming-Sung Kuo's claim that we are witnessing the 'end of constitutionalism as we know it' in Ming-Sung Kuo, The End of Constitutionalism as We Know It? Boundaries and the State of Global Constitutional (Dis)ordering, 1 TRAnSNAT'L Legal TheORY 329 (2010). Additionally, see Nico Krisch's assertion that in 'postnational governance' the 'classical forms' of constitutionalism are not sustainable in Nico Krisch, BEYond Constitutionalism: The PluRAlist Structure OF Postnational LaW 17 (2010). For summary of this controversy, see Oliver Diggelmann \& Tilmann Altwicker, Is there Something like a Constitution of International Law? A Critical 
with anxiety about the loss of sovereign territorial jurisdiction and literature that identifies the homology of power and geographical terrain as hopelessly outworn. ${ }^{3}$ Moreover, one increasingly influential line in this field of analysis identifies transnational constitutional law as arising specifically from legal exchanges situated beyond the conventional constitutional sphere of public law and as not originally reliant on acts of public-legal bodies: that is, it argues that transnational law results from the hybridization of international public and international private law in the normatively fluid and deeply heterarchical processes of legal norm construction in global society. ${ }^{4}$

This article is not the place to reconstruct all the divergent threads of such debates. However, what appears between the lines of all these bodies of literature is the sense that the constitutional form of contemporary society reflects a demise of (what are perceived to be) the classical principles of constitutionalism. That is, it is commonly suggested that this constitutional form reflects the diminishing importance of the constitution as one written document or set of documents that, originally underpinned by the popular will, prescribe a hierarchy of legal norms and strictly allocate powers within a national

Analysis of the Debate of World Constitutionalism, 68 ZEITSCHRIFT FÜR AUSLÄNDISCHES ÖFFENTLICHES RECHT UND VÖLKERRECHT 623 (2008).

3. In the former category, see JEREMY A. RABKIN, LAW Without Nations? WhY CONSTITUTIONAL GOVERNMENT REqUIRES SOVEREIGN STATES 70 (2007); Ernest A. Young, The Trouble with Global Constitutionalism, 38 TEX. INT'L L. J. 527, 536, 542 (2003). In the latter category, see ANDREAS FISCHER-LEsCANO \& GUNTHER TEUBNER, Regime-Kollisionen. Zur Fragmentierung Des Globalen ReChts [Collision of Regimes. ON THE Fragmentation OF GLOBAL LAW] 24 (2006) (Ger.); MaRTTI Koskenniemi, The Politics Of International LaW (2011); Paul Schiff Berman, $A$ Pluralist Approach to International Law, 32 YALE L.J. 301, 314 (2007); Paul Schiff Berman, Global Legal Pluralism, 80 S. CAL. L. Rev. 1155, 1231 (2007); and Martti Koskenniemi \& Paivi Leino, Fragmentation of International Law? Postmodern Anxieties, 15 LEIDEN J. INT'L L. 553, 555 (2002).

4. This approach was initiated by Gunther Teubner, and it has since been extended by others, notably by Peer Zumbansen. Despite my great respect for this line of research, I wish to be clear that my definition of the transnational constitution deviates from that promoted in this literature. I am of the view that a transnational legal order that can reliably be categorized as a constitution is still situated primarily in the realm of public law, albeit not necessarily national public law. At a transnational level, this constitution is primarily created through the interaction between judicial actors. For my longer discussion of, and debate with, this literature see Chris Thornhill, National Sovereignty and the Constitution of Transnational Law: A Sociological Approach to a Classical Antinomy, 3 TransNaT'L LEG. TheORY 394-414 (2012). Specifically, I understand transnational constitutional law as a body of legal norms, primarily produced by courts, that evolves between the national and the international levels. Such law is situated outside national societies, but it is not willed by sovereign state actors and it is not reducible to international law, and it moves between national and supranational domains through complex and uncertain processes of filtration. 
state, which itself exercises fixed public control of a particular societal domain, and possesses monopolistic (although normatively curtailed) authority for the production of laws in this territory. ${ }^{5}$ Above all, different bodies of literature treating the transformation of constitutional law are unified by the fact that they intuit a decline in the force of sovereign constituent power and democratic legislative power more generally as a determinant of modern transnational constitutionalism. ${ }^{6}$ All lines of analysis, whatever their disposition towards the global constitution, concur in claiming that the existence of a pre-legal constituent will has been lost in modern society, and normative expectations derived from an arena outsides national society now place prior constraints on all legal acts. In contemporary society, thus, transnationally acceded norms (usually shaped by rights) determine the prior form of national laws, and law can no longer be traced to a founding point of regress. ${ }^{7}$ The origin of binding law is now in fact commonly law itself, and law (even primary, constitutional law) is habitually derived from other laws: law is typically derived from laws established through international charters, conventions, treaties, and, above all, courts with authority to enforce international agreements regarding rights. ${ }^{8}$ Because of this, it is commonly argued that the

5. For a relatively recent version of this theory see MARTIN LOUGHLIN, THE IDEA OF PUBLIC LAW, 43-44 (2003). For the most committed, pluralistic repudiation of this hierarchical, mono-focal theory of constitutional order see Peer Zumbansen, Comparative, Global and Transnational Constitutionalism: The Emergence of a Transnational Legal-Pluralist Order, GLOB. CON. 48 (2012).

6. Parliaments have recently been described as "outmoded nineteenth-century institutions," of necessity bound to cede ground to constitutional courts. This view was expressed in 2002 by the then President of the Spanish Constitutional Court. This opinion is quoted here from Saïd Amir Arjomand, Law, Political Reconstruction and Constitutional Politics, 18 INTER'L Sociology 27 (2003). Elsewhere, it is observed that legislative sovereignty has simply 'disappeared' in recent years. See Alec Stone Sweet, Constitutions and Judicial Power in Comparative Politics 218 (Daniele Caramani, ed, 2008).

7. See the deviation from the classical doctrine of constituent power as pre-legal force as developed in Raymond CarRé De Malberg, 2 Contribution A La THEORIE gENERALE DE L'État [CONTRIBUTION TO THE GENERAL THEORY OF THE STATE] 490-91 (1920-22). For a more recent neo-classical version on this theory, see ERNST-WOLFGANG BöCKENFÖRDE, STAAT, VERFASSUNG, DEMOKRATIE. STUdIEN ZUR VERFASSUNGSTHEORIE UND ZUM VerfassungsRecht [STATE, CONSTITUTION, StUdies on TheORIES OF tHE CONSTITUTION AND CONSTITUTIONAL LAW] 90-91 (2nd ed., 1991) (Ger.). On the absence of such power under present societal conditions, see the account in Neil Walker, The Idea of Constitutional Pluralism, 65 MOD. L. REv. 317, 340 (2002).

8. See Rainer Nickel, Legal Patterns of Global Governance: Participatory Transnational Governance, in CONSTITUTIONALISM, MUlTileVel TRADE GovernanCE AND INTERNATIONAL ECONOMIC LAW 158 (Christian Joerges \& Ernst-Ulrich Petersmann eds., 2011) (providing that "it is widely acknowledged and well documented that supranational and international entities or arrangements play an increasing role in the shaping of national law"); Eyal Benvenisti \& George W. Downs, National Courts, Domestic 
classical constitutional antinomy between constituent and constituted power has been effaced: now all power, even the power to found new constitutions, is legally pre-constituted, and textbook examples of constituted power (in particular, judicial actors) routinely construct constitutional norms and so exercise de facto constituent power across national divides. ${ }^{9}$ As a consequence of this, norms applied by constituted judicial actors (especially in respect to rights) become recurrent depositories of constituent power, and they act as preconditions for constitution-making in multiple societal settings. ${ }^{10}$ This might in fact be observed as the general fate of contemporary constitutionalism: constituent and constituted power become inseparable, and traditional checks on constituent power (rights norms applied by courts) become, as they are transplanted across different national settings, mobile sources of already constituted constituent power. As a result, the decision of constituent power, which is supposed in classical constitutional doctrine to underwrite all constitutional legitimacy, ${ }^{11}$ is dispersed into isolated sources of validity at different points or tiers in the transnational legal/political system. Democratically mandated actors thus merely operate as bodies placed alongside other centers of legal force, and they are defined and constrained by judicial bodies, deriving authority from international judicial norms. ${ }^{12}$ The outcome of this is that, as is typical under political systems with an elevated obligation to rights, decision-making power becomes a recursive inner-legal function, and courts, referring for their authority to higher rights norms, become primary bearers of legislative power. ${ }^{13}$

Democracy, and the Evolution of International Law, 20 EUR. J. INTERNAT'L L. 67 (2009); Armin von Bogdandy \& Ingo Venzke, Zur Herrschaft internationaler Gerichte: Eine Untersuchung internationaler öfentlicher Gewalt und ihrer demokratischen Rechtfertigung, 70 ZEITSCHRIFT FÜR AUSLÄNDISCHES UND ÖFFENTLICHES RECHT (2010).

9. For discussion of the conventional status of courts as "the exact opposite of the constituent subject" see Joel I. Colón-Ríos, Carl Schmitt and Constituent Power in Latin America: The Cases of Venezuela and Colombia, 18 Constellations 365, 365 (2011).

10. This applies in particular to international organizations, such as the UN, whose judicial norms are routinely incorporated in national law to underwrite new constitutions. But this also applies to national constitutional courts, which often openly preside over constitution-writing processes.

11. Carl Schmitt, Verfassungslehre [Constitutional Theory] 21 (1928) (Ger.) (discussing constitutional legitimacy in the Weimar Republic).

12. See, e.g., Benvenisti \& Downs, supra note 8 , at $65,67,69$.

13. The classical historical example is the United States, where the Bill of Rights, and, more especially, the Fourteenth Amendment, were intended (arguably, at least) to enable courts to act as de facto lawmakers. For accounts of the role of rights in conferring quasi-legislative power on courts, see ROBERT A. BURT, THE CONSTITUTION IN CONFLICT 127, 227 (1992) and Sol Wachtler, Judicial Lawmaking, 65 N.Y.U. L. REv. 1, 8 (1990). On the implications of the Fourteenth Amendment in this regard, see ROBERT J. Kaczorowski, The Nationalization Of Civil Rights: Constitutional Theory AND 
This elision of constituent power and constituted power in the actions of transnational judicial bodies, and especially in the judicial application of rights, characterizes contemporary constitutionalism in many ways. In particular, it characterizes contemporary constitutionalism at the level of national and international public law, and it characterizes the more informal constitutional order of the distinct functional domains in transnational society.

\section{Political Rights and Political Sovereignty}

\section{A. A-constituent National Polities}

One way in which judicial institutions and their rights jurisprudence exercise constituent power is evident in public law at a national level. As discussed below, this is seen in the rapidly increasing prominence of national judges, especially those sitting on constitutional courts, as political actors. ${ }^{14}$ It is reflected in the near inevitability that constitutional courts armed with strong powers of statutory review, typically founded in international law and international rights obligations, will act as primary (often founding) components of any national constitutional order.

The growth of judicial power is a particular feature of new, post-transitional constitutions, and transitional political systems are typically shaped by the growing force of judicial power in a variety of ways. For example, the rising importance of constitutional courts, ensuring the primacy of international rights over national law, was evident first in the democratic transitions in Germany and Italy after $1945 . .^{15}$ It was then cemented in the second wave of democratic transitions of the 1970s, where judicial review, exercised to ensure national compliance with international human rights standards, played a vital role in the stabilization of democratic statehood in national settings. ${ }^{16}$ After this, constitutional courts, enunciating international

PRACTICE IN A RACIST SOCIETY 1866-1883, at 210 (1987). This of course does not imply that the expectations attached to the Fourteenth Amendment were fulfilled.

14. See for classical analysis Carlo Guarnieri \& PATrizIa Pederzoli, The Power Of JUdGeS: A COMPARATIVE STUDY OF COURTS AND DEMOCRACY 11 (2002); Neal C. Tate, Why the Expansion of Judicial Power? in THE GLOBAL EXPANSION OF JUDICLAL POWER (Neal C. Tate \& Torbjörn Vallinder, eds. 1995); RAN HIRSCHL, TOWARDS JURISTOCRACY: THE Origins AND The Consequences OF THE NEW Constitutionalism (2004).

15. See my recent discussion in Chris Thornhill, National Sovereignty and the Constitution of Transnational Law: A Sociological Approach to a Classical Antinomy, 3 TRANSNAT'L LEG. THEORY (2012).

16. See António Araújo, A Construção da Justiça Constitucional Portuguesa: o Nascimento do Tribunal Constitucional [the Construction of Portuguese Constitutional 
norms as the basis for national laws, assumed the greatest prominence in the reforms conducted in transitional states in the later 1980s and early 1990s, at which time judicial actors clearly began to blur the distinction between constituted and constituent power.

The patterns of judicial policy-making in many Eastern European societies were at the forefront of this process. In Poland, for example, courts of review assumed growing significance prior to the pro-democratic upheavals of the late $1980 \mathrm{~s},{ }^{17}$ and after 1989 the Polish Constitutional Court authorized itself, through reference to international rights standards, to initiate and to perform functions both of normal legislation and-effectively-of constitutional foundation. ${ }^{18}$ This was paralleled in Hungary, in which the Court established under constitutional amendments of 1989 clearly acted beyond the classical functions of courts as constituted bodies, and it even directly initiated key rafts of primary legislation. ${ }^{19}$ Borrowing authority from international legal codes, both these courts used reference to international accords regarding human rights to establish a normative basis for lawmaking and constitution drafting in lieu of an assembled constituent power. ${ }^{20}$

Justice: the Birth of the Constitutional Court], 30 ANÁlise SoCIAL 881, 905 (1995) (Port.) (providing an account of judicial review and the role it played in stabilizing democratic statehood). See generally Pedro C. Magalhães, Carlo Guarnieri \& Yorgos Kaminis, Democratic Consolidation, Judicial Reform, and the Judicialization of Politics in Southern Europe, in Democracy AND The STATe In The New Southern Europe 138 (Richard Gunther, P. Nikiforos Diamandouros \& Dimitri. A. Sotiropoulos eds., 2006) (providing that the causes and consequences of the creation of other types of political institutions, such as the judiciary, have been widely neglected in regions such as Southern Europe).

17. Independent courts of review were unusual in Eastern Europe before the 1980s. One was created, but never became operative, in Czechoslovakia in 1968. They also existed in Yugoslavia. But it was only in Hungary and Poland that they played a significant role before 1989. See generally CATHERINE DUPRÉ, IMPORTING THE LAW IN Post-Communist Transitions: The Hungarian Constitutional Court And The Right To Human Dignity 5-7 (2003); Mark F. Brzezinski \& Lezek Garlicki, Judicial Review in Post-Communist Poland: The Emergence of a Rechtsstaat?, 31 STAN. J. INT'L L. 13, 31 (1995).

18. Wiktor Osiatynski, Rights in New constitutions of East Central Europe, 26 Columbia Hum. RTS. L. REv. 164 (1994).

19. András Sajó, Reading the Invisible Constitution: Judicial Review in Hungary, 15 OXFORD J. LEGAL STUD. 253, 257 (1995) (providing examples of the Court's philosophy that "constitutionalism has to be interpreted under the 'unique and special circumstances of regime transformation").

20. See RAdOSLav Procházka, Mission Accomplished: On Founding AdJUdication IN CENTRAL EUROPE 209-10 (2002) (providing that this was especially prominent in Poland, prior to the enforcement of the 1997 Constitution). On the extraordinary competence of the Hungarian court see Herbert Küpper, Völkerrecht, Verfassung und Außenpolitik in Ungarn, 58 ZEITSCHRIFT FÜR ÄUSLANDISCHES ÖFFENTLICHES RECHT UND VÖLKERRECHT 267 (1998). 
This process was soon reflected and intensified in other transitional contexts. A prominent case was South Africa, where, in its second stage, the constitution-writing process was placed under the guardianship of the Constitutional Court, which was strongly authorized to activate international law as the basis for domestic rulings and legislation. ${ }^{21}$ This was also a notable feature in some South American transitions. In some parts of South America, even in settings marked by extreme levels of social violence, by historically low degrees of judicial independence, and even by an ongoing institutional attachment to weakly constrained super-presidentialism, ${ }^{22}$ the creation of courts with strong powers of rights-based judicial review became an increasingly mandatory institutional norm. ${ }^{23}$ In some South American societies, constitutional courts and judicial institutions more generally became vital instruments of democratic consolidation. ${ }^{24}$ Notably, in Colombia, Costa Rica, and Brazil, judicial review has become a vital pillar of the governmental system. ${ }^{25}$ The case of Chile has particular distinction in this regard, as the Chilean Constitutional Court, by initial design a repressive instrument of dictatorship, provided cautious impetus for democratic-constitutional reorientation towards the end of the Pinochet

21. See John Dugard, International Law and the South African Constitution, 8 EUR. J. INT'L L. 77, 78 (1997) (providing that the Constitutional Court actively oversaw the drafting of the constitution before it was approved).

22. Note the case in Argentina, where, after 1990, President Menem often governed, to a large degree, by emergency decree, and he routinely promoted court packing to simplify his prerogative system of authority. Even in this case, however, constitutional revisions of 1994 led (ultimately) to a strengthening of judicial power and autonomy. See on this Rebecca Bill Chavez, The Evolution of Judicial Autonomy in Argentina: Establishing the Rule of Law in an Ultrapresidential System, 36 J. LATIN AMER. STUDS 453 (2004); Gabriel L. Negretto, Constitution-Making and Institutional Design. The Transformations of Presidentialism in Argentina, 40 EUR. J. SocIOLOGY 212-14 (1999).

23. See, e.g., Rodrigo Uprimny Yepes, Judicialization of Politics in Colombia: Cases, Merits and Risks, 6 INT'L J. HUM. RTS. 49, 49 (2007) (analyzing the judicialization of politics in Colombia). See generally Pilar Domingo, Judicialization of Politics or Politicization of the Judiciary? Recent Trends in Latin America, 11 DEMOCRATIZATION 104 (2004) (examining the judicialization of politics in Latin America with particular reference to Mexico and Argentina); Patricio Navia \& Julio Ríos-Figueroa, The Constitutional Adjudication Mosaic of Latin America, 38 COMP. POL. STUD. 189 (2005) (mapping current constitutional adjudication systems in seventeen Latin American democracies).

24. See LINN HAMMERGREN, ENVISIONING REFORM: IMPROVING JUDICIAL PERFormance IN LATIN AMERICA 9 (2007).

25. See Julio Faundez, Democratization through Law: Perspectives from Latin America, 12 DEMOCRATIZATION 758 (2005). For discussion of the singularly powerful status of the Constitutional Court in Costa Rica, see Thomas Buergenthal, Modern Constitutions and Human Rights Treaties, 36 ColUM. J. TRANSNAT'L L. 218 (1998). 
regime. ${ }^{26}$ In recent and still ongoing democratic transitions, similar processes can be observed. The tentative moves towards the consolidation of democracy in many states in sub-Saharan Africa in the last decades have commonly involved the establishment of powerful courts applying rights-based jurisprudence to uphold constitutional order. ${ }^{27}$ In recent regime changes in North Africa we can observe, in heightened form, a process of judicial constitution writing, in which courts assume a prominent-an abidingly contested-role in polity building, and international norms, mediated through courts, create parameters for primary acts of lawgiving, even against religious backgrounds seemingly favoring alternative outcomes. ${ }^{28}$

This judicializing tendency in national polities, however, is not exclusive to transitional societies. Even securely established democratic states, such as the United Kingdom and France, which are marked by strong historical attachment to powerful sovereign legislatures and entrenched opposition to judicial lawmaking and formal rights, are not immune to the rising constitutional primacy of rights. ${ }^{29}$ These states have also incorporated extensive procedures for rights-based review in their constitutions, rendering them accountable to the case law of international courts, notably the European Court of Human Rights

26. See Robert Barros, Constitutionalism And Dictatorship: Pinochet, The JUNTA, AND THE 1980 CONSTITUTION 266 (2002) (describing the Pinochet regime and its constitutional history).

27. For general comment, see Richard Frimpong Oppong, Re-Imagining International Law: An Examination of Recent Trends in the Reception of International Law into National Legal Systems in Africa, 30 FoRDHAM INT'L L.J. (2006); Kwasi Prempeh, Marbury in Africa: Judicial Review and the Challenge of Constitutionalism in Contemporary Africa, 80 TUL. L. Rev. 1241, 1242 (2006); Kwasi Prempeh, Africa's "Constitutionalism Revival": False Start or New Dawn, 5 INT'L CONSTITUTIONALISM 505 (2007).

28. In the case of Egypt in particular there existed a powerful and semi-independent judiciary before the fall of Mubarak, and encroachment on judicial autonomy was one cause of revolutionary backlash in 2011. See generally Tamir Moustafa, Law versus the State: The Judicialization of Politics in Egypt, 28 LAW \& SOC. INQUIRY 883 (2003); Lama Abu Odeh, The Supreme Constitutional Court of Egypt: The Limits of Liberal Political Science and CLS Analysis of Law Elsewhere, 59 AM. J. CoMP. L. 985, 996-97 (2011). The extent of the autonomy of judicial power created a framework for mobilization of human-rights norms in Egypt. See generally Mona El-Ghobashy, Constitutionalist Contention in Contemporary Egypt, 51 AM. BEHAV. ScIENTIST 1590 (2008) ("[T]ackl[ing] the problem of political-institutional change in undemocratic regimes commonly considered impervious to meaningful political contention."). The Supreme Constitutional Court has remained a powerful actor during the post-Mubarak interim, and it has continued to exercise review of pre-constitutional statutes.

29. For specific examples, see Federico Fabbrini, Kelsen in Paris: French Constitutional Reform and the Introduction of a posteriori Constitutional Review of Legislation, 9 GER. L. J. (2008). 
(ECtHR). ${ }^{30}$ The newly established primacy of rights in such polities means that these political systems have substantially undermined the autonomy of their legislatures, ${ }^{31}$ ceded far-reaching lawmaking power to courts, ${ }^{32}$ and, especially in the case of the United Kingdom, assumed a new constitutional order without recourse to a classical or primary constituent act.

These developments have imprinted a number of relatively common constitutional hallmarks on contemporary national societies. First, these developments result in a situation in which legislative decisions, at the constitutional, statutory, substatutory and pre-statutory level, are habitually shaped or even struck down by judges in constitutional courts. In most national states, each act of sovereign legislation co-implies close judicial scrutiny in light of international rights obligations. Second, these developments have the outcome that national legislatures integrate interpreters of rights as potent veto players in their legislative procedures, such that uniform rights determinably shape legislation even where they are not overtly applied to constrain or reverse legislative decisions. ${ }^{33}$ Third, and most importantly, these

30. See the UK Human Rights Act (1998), which was designed to "give further effect to rights and freedoms guaranteed under the European Convention on Human Rights." For comment on the constitutional implications of this see Jo Eric Kuhushal Murkens, The Quest for Constitutionalism in UK Public Law Discourse, 29 OX. J. LEG. STUDS, 435-36 (2009).

31. See Aileen Kavanagh, Constitutional Review Under The UK Human Rights ACT 114, 275 (2009) (setting out that parliament did not grant the interpretive powers or review to the courts); DANNY NICOL, EC MEMBERSHIP AND THE JUDICIALIZATION OF BRITISH POLITICS 226 (2001) ("[T]he supervisory jurisdiction of the Divisional Court now extends to declaring an Act of Parliament incompatible with Community law without recourse to Luxembourg."); K. D. Ewing, The Human Rights Act and Parliamentary Democracy, 62 MOD. L. REV. 79, 79 (1999) (noting the Human Rights Act of 1998 "represents an unprecedented transfer of political power from the executive and the legislature to the judiciary, and a fundamental restructuring of our 'political constitution"'). See the account of the final 'painless death' of parliamentary sovereignty in France, its traditional heartland, in ALEC STONE SwEET, THE CONSTITUTIONAL CounCIL AND The TRANSFormation of THE REPUblic (2008) (Yale L. School Faculty Scholarship Series Paper 79). See also Mitchel De S.-O.-L'E LASSER, Judicial Transformations: The Rights Revolution In The Courts Of EuRoPe 24 (2009) (discussing fundamental rights in the French and European judiciaries).

32. See Aileen Kavanagh, The Elusive Divide Between Interpretation and Legislation Under the Human Rights Act 1998, 24 OX. J. LEGAL STUD. 259, 261, 267, 284 (2004) (analyzing the court's distinction between interpretation and legislation).

33. See generally Janet L. Hiebert, New Constitutional Ideas: Can New Parliamentary Models Resist Judicial Dominance when Interpreting Rights?, 82 TEx. L. REv. 1963 (2004) (examining how the parliamentary right model "paradigm conceives of institutional roles and responsibility or judgments about rights, with a specific focus on the Canadian Charter of Rights and Freedoms (Charter) and the United Kingdom's Human Rights Act"); Loïc Philip, Bilan et effets de la saisine du Conseil constitutionnel [Balance and Effects of 
developments have the consequence that, especially in transitional contexts, courts often create and interpret a framework of constitutional law ex nihilo. In such cases, courts have, to all intents and purposes, assumed the (at least intermittent) capacity to exercise constituent power and to embody constituted authority at one and the same time. Across national divides, supra-constitutionalized rights are now accorded a normative force in legislation, such that rights act as authoritative surrogates for constituent power. Legislation is typically and primarily proposed as legitimate if it accords with rights derived originally from an international legal order. Polities require little constituent force except that of actors enunciating rights, and, across a spectrum of variations, national polities are increasingly formed by the auto-constituted power of courts, which authorize these system-building functions by borrowing constituent power from an already established international legal domain.

\section{B. A-constituent Multinational Polities}

In analogy to this, a further way in which courts and their rights jurisprudence assume constituent force in society is evident in the politically formative role of courts in the public law of supra- or transnational polities and supra- or transnational legal communities, such as the European Union or-to a lesser extent-the World Trade Organization (WTO). ${ }^{34}$ For example, it is widely accepted that, in the emergence of the de facto constitution of the European Union, the law courts-especially the European Court of Justice (ECJ), but to some degree also the ECtHR-utilized powers of rights adjudication to assume a position filled in more classical polities by constitutional assemblies or elected legislatures. ${ }^{35}$ In particular, the ECJ, standing as an example of "the highest degree of judicialization,"36 established a doctrine of judicial supremacy and direct effect, which has brought different national systems into convergence on key points of policy and applied norms with effective constitutional standing across all member

Referral to the Constitutional Council], 4 REvUe Française De SCIENCE Politique 988 (1984) (discussing the extension of the right of reference to the Constitutional Council).

34. See generally Eric Stein, Lawyers, Judges, and the Making of a Transnational Constitution, 75 AM. J. INT'L L. 1 (1981) (providing a classical perspective).

35. On the ECtHR in this respect, see STEven GREER, THE EuROPEAN CONVENTION ON Human Rights: Achievements, Problems and Prospects 317 (2006). On the role of the ECJ as a 'permanent pouvoir constituant' see ANNE PETERS, ElEMENTE EINER THEORIE Der Verfassung Europas [Elements of a Theory for a European Constitution] 401-03 (2001) (Ger.).

36. Carl Baudenbacher, Judicialization: Can the European Model Be Exported to Other Parts of the World?, 39 TEX. INT'L L.J. 381, 391 (2004). 
states of the European Union. ${ }^{37}$ One primary result of this is that supraor transnational legal obligations, not in their full constitutional extent ratified by elected assemblies, acquire nonderogable status both within the overarching polity of the European Union and within the increasingly subsidiary legislative systems of constituent states. ${ }^{38}$

In the case of the ECJ, most notably, the always uncertain relation between constituent power and constituted power is elided-almost autologically-into a system in which the constituted power of a court exercises the force of a constituent body and establishes a series of constitutional norms to determine a founding legal order, having an impact at a national and at a transnational level. ${ }^{39}$ Through this

37. See the recent description of the ECY as the 'very locus of Europeanization' in Antoine Vauchez, The Transnational Politics of Judicialization and the Making of the EU Polity, 16 EUR. L.J. 3 (2010).

38. On the constitutionalization of the Treaty of Rome by the ECJ as a process leading to a deep constitutional transformation of Members States, see Eric Stein, Gerhard Casper, John W. Bridge, Stefan A. Riesenfeld, Pieter VerLoren van Themaat \& Ami Barav, The Emerging European Constitution, 72 ProceEdings Of The ANNUAL MEETING OF THE AMERICAN SOCIETY OF INTERNATIONAL LAW 173 (1978).

39. In the European Union, it is argued, there is "no scope for creation ex nihilo of a distinctive constituent power." Neil Walker, Post-Constituent Constitutionalism? The Case of the European Union, in THE PARAdox of Constitutionalism: Constituent Power AND Constitutional Form 247, 259 (Neil Walker \& Martin Loughlin eds., 2007). See also Neil Walker, Reframing EU Constitutionalism, in RULING THE WORLD? Constitutionalism, International LaW, AND GLobal Governance 149, 172-74 (Jeffrey L. Dunoff \& Joel P. Trachtman eds., 2009) (discussing multiple problems in the drafting of any future European constitution). In agreement for different reasons, see JAN KLABBERS ET AL., The CONSTITUTIONALIZATION OF InTERNATIONAL LAW 179 (2009); PETERS, supra note 35, at 426. On the autonomy of European Union law, see critical comment in Theodor Schilling, The Autonomy of the Community Legal Order: An Analysis of Possible Foundations, 37 HARV. INT'L L.J. 389, 395 (1996). For the classic study of court-led foundation in the European Union, see J.H.H. Weiler, The Transformation of Europe, 100 YALE L.J. 2403 (1991). For detailed empirical accounts, see KAREN J. ALTER, Establishing The Supremacy Of European LaW: The Making OF AN International RULE OF LAW IN EUROPE (2001); Karen J. Alter, Who Are the "Masters of the Treaty"?: European Governments and the European Court of Justice, 52 INT'L ORG. 121 (1998); Anne-Marie Burley \& Walter Mattli, Europe Before the Court: A Political Theory of Legal Integration, 47 INT'L ORG. 41, 71 (1993) (setting out a highly illuminating account of the ECJ as an institution leading integration by "transforming the political into the legal"); Id. at 75 (establishing a European polity based in the autonomy - "the internally sustained power"-of law). See also the claim in ALEC STONE SWEET, THE JUDICIAL CONSTRUCTION OF EUROPE 65 (2004) that the ECJ has engendered a "constitutionalization" of the European Union that is "binding upon sovereign states into a vertically integrated legal regime." See also Alec Stone Sweet \& Thomas L. Brunell, Constructing a Supranational Constitution: Dispute Resolution and Governance in the European Community, 92 AM. POL. SCI. REV. 63 (1998) (arguing that transnational acts effect the way that the European Community has integrated itself). For nuanced inquiry, see Gráinne de Búrca, Sovereignty and the Supremacy Doctrine of the European Court of Justice, in SOVEREIGNTY IN 
process, the ECJ has been able to act as an institution conducting constitutional supervision and review for a constitution that does not formally exist, and which it itself, in the ongoing process of interpretive review, factually and spontaneously (i.e. acting as effective constituent power) promulgates, reinforces, and perpetuates. ${ }^{40}$ Similar tendencies, in weaker form, have been observed in the WTO.41 In the European Union, this a- or auto-constituent pattern of constitutional consolidation has been made possible by, and has derived far-reaching legitimacy from, the fact that the ECJ has assumed normative authority by virtue of its claim to base rulings in prior international rights. ${ }^{42}$ To be sure, the ECJ's obligation to international rights rorms was originally weak, and it initially differentiated its jurisprudence from that of the ECtHR. ${ }^{43}$

TRANSITION 449 (Neil Walker ed., 2003). More recently, see the sociological account of this in Antoine Vauchez, The Force of a Weak Field: Law and Lawyers in the Government of the European Union (For a Renewed Research Agenda), 2 INT'L POL. Soc. 128 (2008); Antoine Vauchez, 'Integration-through-Law': Contribution to a Socio-history of EU Political Commonsense (Eur. U. Inst., Working Papers RSCAS 2008/10, 2008).

40. Michel Rosenfeld, Comparing Constitutional Review by the European Court of Justice and the U.S. Supreme Court, 4 INT'L J. CONST. L. 618, 619 (2006).

41. For the ascription of such functions to the Appellate Body of the WTO, see Joel P. Trachtman, The Constitutions of the WTO, 17 EUR. J. INT'L L. 623, 639-40 (2006); Deborah Z. Cass, The 'Constitutionalization' of International Trade Law: Judicial Norm-Generation as the Engine of Constitutional Development in International Trade, 12 EUR. J. INT'L L. 39, 42, 44, 60, 71-72 (2001); DeboraH Z. CASS, THE CONSTITUTIONALIZATION OF THE WORLD TRADE ORGANIZATION: LEGITIMACY, DEMOCRACY, AND COMMUNITY IN THE INTERNATIONAL TRAdING SYSTEM 22 (2005); Richard H. Steinberg, Judicial Lawmaking at the WTO: Discursive, Constitutional, and Political Constraints, 98 AM. J. INT'L L. 247, 248 (2004). For a contrast of the quasi-constitutional powers of the European Union and the WTO, see Neil Walker, The EU and the WTO: Constitutionalism in a New Key, in THE EU AND THE WTO: LEGAL AND CONSTITUTIONAL IsSUES (Gráinne de Búrca \& Joanne Scott eds., 2001); Peter Holmes, The WTO and the EU: Some Constitutional Comparisons, in THE EU AND THE WTO: LEGAL AND CONSTITUTIONAL ISSUES, supra.

42. See Steven Greer \& Andrew Williams, Human Rights in the Council of Europe and the EU: Towards 'Individual', 'Constitutional' or 'Institutional' Justice?, 15 EUR. L.J. 462, 478-79 (2009) (arguing that the European Union has claimed its legitimate existence through the European Courts' protection of human rights); G. Federico Mancini \& David T. Keeling, Democracy and the European Court of Justice, 57 MODERN L. REv. 175, 179, 181 (1994) (discussing how the ECJ has used rights and the democratic principle to define what is legitimate legislation); Sionaidh Douglas-Scott, Europe's Constitutional Mosaic: Human Rights in the European Legal Space-Utopia, Dystopia, Monotopia or Polytopia?, in EuRope's Constitutional Mosaic 97, 128-29 (Neil Walker, Jo Shaw \& Stephen Tierney eds., 2011) (discussing how judicial decisions from various sources like the ECJ and the ECtHR can create a better body of human rights law in the European Community); Sionaidh Douglas-Scott, A Tale of Two Courts: Luxembourg, Strasbourg and the Growing European Human Rights Acquis, 43 CoMmon MKT. L. REv. 629, 645 (2006) (discussing the ECJ's reference to the ECHR as a source for rights jurisprudence).

43. See Armin von Bogdandy, The European Union as a Human Rights Organization? Human Rights and the Core of the European Union, 37 COMMON MKT. L. REV. 1307, 1336 
However, since the late 1960s, the normative power of the ECJ has been increasingly underscored by its commitment to rights-based norms, and, in response to challenges from national (especially German) courts, its jurisprudence has been strongly influenced by the European Convention on Human Rights (ECHR) and rulings of the ECtHR. ${ }^{44}$ In fact, the ECJ originally designated itself as bound by a jurisprudence of rights. ${ }^{45}$ Without specific authorization by the original European Economic Community (EEC) treaties, the ECJ spontaneously constituted itself as a constituent actor by claiming a mandate to apply rights as the basis for its quasi-constituent acts and to review Community acts in relation to fundamental rights norms. In so doing, it also independently defined rights as constitutive elements of the normative order of the European Union, able to override, and penetrate into, national laws. ${ }^{46}$

This is evident in a number of landmark cases decided by the ECJ. For instance, in Stauder (1969) and Internationale Handelsgesellschaft (1970), the ECJ accorded validity to its rulings by stating that rights norms should be viewed as essential elements of European jurisprudence, and it even insisted that fundamental rights needed to be seen as "general principles" of European law. ${ }^{47}$ Against the background of its recurrent jurisdictional conflicts with the

(2000) (asking if European law should be "freed from its function as an instrument of polictically induced social change."); Jason Coppel \& Aidan O'Neill, The European Court of Justice: Taking Rights Seriously?, 12 LEGAL STUD. 227, 245 (1992) (arguing that while the ECJ has grown more conscious of human rights issues, it is still reluctant to impose rights protections over economic integration).

44. See LASSER, supra note 31, at 225; Nico Krisch, The Open Architecture of European Human Rights Law, 71 MODERN L. REV. 183, 198-99 (2008) (discussing the development of the relationship between the ECJ and the ECtHR since the 1970s); Tobias Lock, The ECJ and the ECtHR: The Future Relationship Between the Two European Courts, 8 L. \& PRAC. OF INT'L CTS. \& TRIBS. 375, 377 (2009) (stating that European Member States are bound by both Community law and the ECHR); Jenny S. Martinez, Towards an International Judicial System, 56 STAN. L. REV. 429, 445-47 (2003) (discussing the relationship between the ECJ and the German Constitutional Court).

45. For general comment, see Mikael Rask Madsen, Human Rights and European Integration: From Institutional Divide to Convergent Practice, in LAW AND THE Formation Of Modern EuRope: Perspectives From The Historical Sociology OF LAW (Mikael Rask Madsen \& Chris Thornhill eds., forthcoming 2014).

46. See Gráinne De Búrca, Fundamental Human Rights and the Reach of EC Law, 13 Ox. J. LEg. STUDS 306 (1993). For more extensive analysis, see Chris Thornhill, The Formation of a European Constitution: An Approach from Historical-political Sociology, 8 INT'L J. L. IN CONTEXT 354 (2012).

47. ANDREW Williams, EU HUMan Rights Policies: A Study in IRony 145 (2004). It is argued that through Stauder and subsequent cases the ECJ "fleshed out" an effective Bill of Rights to support its rulings. Henri de Waele, The Role of the European Court of Justice in the Integration Process: A Contemporary and Normative Assessment, 6 HANSE L. REV. 3, 5 (2010) (Ger.). 
Bundesverfassungsgericht (BVG), the ECJ explained its judgments in Nold (1974) and Rutili (1975) through reference to the ECHR. ${ }^{48}$ By the later 1980s, and especially after the BVG's acceptance of rights thresholds applied by the ECJ in Solange II (1986), it became more commonly acknowledged that human rights should be viewed as forming core aspects of European jurisprudence and indeed of the entire institutional architecture of the European Union. ${ }^{99}$ In Hubert Wachauf v. Bundesamt fur Ernährung und Forstwirtschaft (1989), notably, the ECJ decided that actions of Member States should be reviewed for compliance with fundamental rights. The Treaty on the European Union now defines Art. 2 "respect for human rights" as a common pillar of the European Union. Moreover, by 2011, the ECJ ruled, in Ruiz Zambrano, that "the genuine enjoyment" of rights obtained by persons "by virtue of their status as citizens of the Union" should be taken as a normative ideal for its case law..$^{50}$

Overall, consolidation of rights norms as a foundation of European law is a core achievement of the ECJ, and the ECJ, interacting with the ECtHR, has promoted quasi-constitutional rights jurisprudence through concerted (although of course recurrently contested) collaboration with other courts and other rights systems, in so doing solidifying its own position within a network of rights jurisprudence. ${ }^{51}$ In consequence, the

48. For example, in Stork (1959), the ECJ stated that human rights norms were not relevant to its jurisprudence. Yet, by 1974 , as its controversies with the BVGH were coming to a head, the ECJ declared in the Nold decision that "international treaties for the protection of human rights" (thus including the European Convention) were to be taken as "guidelines which should be followed within the framework of community law." See Laurent Scheeck, The Relationship between the European Courts and Integration through Human Rights, 65 ZEITSCHRIFT FUR ÄUSLANDISCHES ÖFFENTLICHES RECHT UND VÖLKERRECHT 850 (2005).

49. As early as 1984, it was stated that: "European integration through fundamental rights is already occurring." See Jochen Abr. Frowein, European Integration through Fundamental Rights, 18 U. MICH. J.L. REFORM 20 (1984-85). One recent commentator even speaks of the "EU's Institutional Turn to Human Rights" in the 1990s. See Mikael Rask Madsen, Human Rights and European Integration: From Institutional Divide to Convergent Practice, in LAW AND THE Formation OF MODERn EuROPE: PERSPECTIVES From THE Historical Sociology OF LAW, supra note 45. See also Armin von Bogdandy, Grundrechtsgemeinschaft als Verfassungsziel, 56 JURISTENZEITUNG 169 (2001).

50. On the implications of this, see Armin von Bogdandy, Matthias Kottmann, Carlino Antpöhler, Johanna Dickschen, Simon Hentrei \& Maja Smrkolj, Reverse Solange-Protecting the Essence of Fundamental Rights against EU Members, 49 COMMON MKT. L. REv. 491, 518 (2012).

51. For a theoretical explanation of this, see Ingolf Pernice, Multilevel Constitutionalism and the Treaty of Amsterdam: European Constitution-Making Revisited?, 36 COMMON MKT. L. REv. 703 (1999) (discussing the effects of the Treaty of Amsterdam on the integration of the European community and the role that the European Court of Justice has to play in that integration); Andreas Voßkuhle, Multilevel Cooperation of the European Constitutional 
ECJ has applied rights to sustain the formation and circulation of political power in a strict and specific disjuncture from any stable assembled demos, in which each Member State has been brought into convergence through vertical checking of domestic statutes against norms asserting authority derived, in part, from human rights. ${ }^{52}$ In the effective constitution of the European Union, judicially-enforced rights form institutions that reflect the specific absence of a constituent demos, and they make it possible for the legal and political system to authorize its acts and to perform functions of inclusion despite its inner diffuseness and low organic integrity and at a very high level of abstraction against firm, external, or constituent acts of will. ${ }^{53}$ Rights provide a quasi-constitutional substructure to give support and legitimacy to originally unfounded, or at least precariously supported, acts of legislation.

Such examples reflect how, both nationally and supra- or transnationally, contemporary society has in some cases begun to build its constitutional form around an elision of constituent and constituted power. If in classical conceptions of constitutional democracy, constituent power formed an originally authorizing point of regress for the political constitution, in contemporary society this status is widely assumed by rights. The preponderance of rights and rights-based institutions in the growing transnational constitution reflects a process in which societies have manufactured consistency for legislation in a highly recursive, often counter-factual fashion. Rights have made it possible for political institutions to distill the basis of law's legitimacy internalistically within the law itself. If classical constitutions

Courts: Der Europäische Verfassungsgerichtsverbund, 6 EUR. CONST. L. REV. 175 (2010) (discussing the integration and cooperation of European courts in the development of constitutional law).

52. See generally Markus Fyrnys, Expanding Competences by Judicial Lawmaking: The Pilot Judgment Procedure of the European Court of Human Rights, 12 GERMAN L.J. 1231, 1254 (2011) (asking if the European Court of Human Rights should engage in constitutional or individual adjudication to deal with the broad range of human rights problems that now confront it). One commentator describes a "triangle that has, at its vertices, the various national supreme or constitutional courts, the ECJK, and the ECtHR" as propelling the process of "constitutionalization" in the European Union. See Lech Garlicki, Cooperation of Courts: The Role of Supranational Jurisdictions in Europe, 6 INT'L CONSTITUTIONALISM 512 (2008).

53. See Miguel Poiares Maduro, The Importance of Being Called a Constitution: Constitutional Authority and the Authority of Constitutionalism, 3 INT'L J. CONST. L. 332, 336-38 (2005) (arguing that the European Union has developed authority independent from its member states); R. DANIEL KELEMEN, EUROLEGALISM: THE TRANSFORMATION OF LAW AND REGULATION IN THE EUROPEAN UNION 24 (2011) (discussing the implication of political fragmentation in the European Union and how it leads to a reliance on adversarial legalism). 
accounted for themselves as authorized by constituent power, standing in an external relation to the law, ${ }^{54}$ the constitution of contemporary society is, to an increasing degree, authorized inner-legally by a pre-constituted or endlessly auto-constituent power stored and reproduced within the law in the form of rights.

\section{ThE SPONTANEITY of THE TRANSNATIONAL CONSTITUTIONAL DOMAIN}

A further way in which judicial actors and rights norms act relatively autonomously to shape the contemporary constitution is visible in the fact that, at different levels of transnational government, a corpus of public law is emerging, whose normative basis is produced through spontaneous acts of self-reference (or auto-constitution) within the legal system. ${ }^{55}$ In this legal order, rights act, at varying societal levels, in internally jus-generative fashion, and they give substance to a self-contained body of legal norms, exercising effective constitutional force across national borders.

The growth of a self-generated system of transnational constitutional law is most obviously apparent at the level of formal constitutional or public-legal organization in national politics. As discussed, the principle that international law has a degree of primacy over national law became pronounced in some national constitutions in the first wave of democratic transition in the late 1940s. ${ }^{56}$ Now it is commonplace for new constitutions to provide a priori (at least hypothetically) for the eventual overruling of national legislation and judicial process by international tribunals applying rulings invoking international norms, obligations, and rights. ${ }^{57}$ The constitutions of Russia and South Africa might be cited as among the most important recent examples of this. ${ }^{58}$ In extreme cases, this culminates in the

54. This originates in Rousseau's idea that the legitimate state must be identical with the will of all society, which must be entirely funneled through the political system.

55. That is to say, public law loses its classical foundation in constituent acts of a sovereign will.

56. The 1949 Constitution of the Federal Republic of Germany gave recognition, in Articles 23,24, 25, 26 and 100(2), to the precedence of international law over national acts of legislation. This was also stipulated in Article 10(1) of the Italian Constitution of 1948.

57. On variations in the application of this norm, see Hurst Hannum, The Status of the Universal Declaration of Human Rights in National and International Law, 25 GA. J. INT'L \& COMP. L. 287 (1996).

58. See the argument for the growing influence of international law on Russian national law in Gennady M. Danilenko, The New Russian Constitution and International Law, 88 AM. J. INT'L L. 451, 461-62 (1994). See also Dugard, supra note 21, at 79 (describing the power of the South African Constitutional Court to evaluate national laws for consistency with international law). In South Africa, the Constitutional Court is instructed by the Constitution to consider international legal sources in its rulings. This 
paradox that constitutional rule can be imposed in single states by actors representing an international normative order, lacking immediate democratic authorization, ${ }^{59}$ such that national constituent power is implicitly pre-configured by a set of transnational normative principles: constituent power is usually a constituted subject before it even exists. However, the emergence of a relatively autonomous body of transnational public law is also evident in supra- or transnational polities, and in particular in the European Union. As considered above, the ECJ's jurisprudence of supremacy has promoted a normative fabric underpinning interstate relations throughout the European Union. This jurisprudence now supports a recursive legal order, or a "circuit of jurisdiction," which is close in normative force to a multi- or transnational constituent power, and in which courts apply internally binding norms (founded in rights) to national-state institutions. ${ }^{60}$ The WTO forms an (albeit weaker) analog to this, and it invokes human rights law to extend its power beyond simple functions of economic dispute settlement and to pre-constitute laws of national states. ${ }^{61}$ Generally, international courts and other appellate actors have assumed a remit that substantially exceeds conventional arbitrational functions. They now increasingly focus on objectives of "norm-advancement": that is, they invoke rights to shape acts of national legislation and, without clear constitutional mandate, to construct a supra- or transnational normative order. ${ }^{62}$

was partly because confidence in indigenous law was low because of its association with the apartheid regime. For analysis, see Margaret A. Burnham, Cultivating a Seedling Charter: South Africa's Court grows its Constitution, 3 MICH. J. RACE \& L. 34 (1997).

59. Philipp Dann \& Zaid Al-Ali, The Internationalized Pouvoir Constituant-Constitution-Making Under External Influence in Iraq, Sudan and East Timor, 10 MAX PLANCK Y.B.U.N.L. 423, 428-29 (2006); Noah Feldman, Imposed Constitutionalism, 37 CONN. L. REV. 858 (2004-5).

60. Giuseppe Bronzini, The European Social Model and the Constitutional Treaty of the European Union, in The ECONOMY AS A Polity: THE POLITICAL Constitution of CONTEMPORARY CAPITALISM 183, 196 (Christian Joerges, Bo Stråth \& Peter Wagner eds., 2005). The tendency toward the promotion of spontaneous judicial lawmaking under human-rights treaties was already acknowledged in more classical literature. See HERSCH LAAUTERPACHT, THE FUNCTION OF LAW IN THE INTERNATIONAL COMMUNITY 263-67 (Oxford Univ. Press 2011) (1933) (discussing conciliation through treaties as an alternative to judicial settlement); PAUL SiegharT, The InTERnational LAW OF HUMAN RIGHTS 43 (1983) (discussing the German principle that international treaties impose a duty on State Parties to provide legislation and regulations to prevent the infringement of rights).

61. Ernst-Ulrich Petersmann, The WTO Constitution and Human Rights, 3 J. INT'L ECON. L. 19, 24 (2000).

62. See the brilliant article Yuval Shany, No Longer a Weak Department of Power? Reflections on the Emergence of a New International Judiciary, 20 EUR. J. INT'L L. 73, 81 (2009). Armin von Bogdandy \& Ingo Venzke, Beyond Dispute: International Judicial Institutions as Lawmakers, 12 GERMAN L.J. 198 (2011). 
In addition, it has been widely observed that contemporary transnational society is developing an internally constructed and relatively autonomous (auto-constituted/auto-constituent) legal system at a less formal level of constitutional organization. This is displayed in particular in the increasing coalescence between different judicial communities and the widespread transportation of legal rulings, norms, and optimal procedures from case to case across national boundaries. ${ }^{63}$ In these processes, rights normally supply broad normative guidelines that promote a judicial lingua franca to facilitate the translation of legal rulings from one national jurisdiction to another. ${ }^{64}$ As a result, recent years have witnessed an increasing comity of national and international courts, through which, in semi-formalized fashion, courts help to construct a system of trans-judicial norms, assuming effective constitutional force in both national and transnational political arenas. ${ }^{65}$ Indeed, it is possible to detect, at least in outline, the emergence of a legal system close in design and standing to a fully elaborated transnational constitution, in which higher-order norms (expressed as rights) are established through international courts, and national or local judicial actors assume (effectively devolved) responsibility for interpreting and filling the legal gaps between these norms. In this respect, courts act as bearers of delegated constituent power to create, at a national level, a subsidiary constitution that is derived, often without strict normative hierarchy, from the first-order norms of international law.

In both of these respects, we can see the emergence of a recursively founded transnational political constitution: that is, a pervasive normative order, which arises from complex interactions between different institutions (primarily courts), situated at different tiers of a transnational political system. In parallel to this political constitution,

63. See Vicki C. Jackson, CONSTitutional Engagement in a Transnational ERA 272 (2009); J.H.H. WEILER, THE CONSTITUTION OF EUROPE 194, 196 (1999) (exploring the reasons that nations would adopt law from the European Community into their own domestic laws). See an excellent analysis of the international enmeshing of national legal structures through the rise of a transnational judicial community in Harold Hongju Koh, How is International Human Rights Law Enforced?, 74 IND. L.J. 1397, 1410-11 (1999); Harold Hongju Koh, Transnational Public Law Litigation, 100 YALE L.J. 2347, 2402 (1991). For a specific case study of the influence of international human rights law on U.S. laws, see Richard B. Lillich, Invoking International Human Rights Law in Domestic Courts, 54 U. CIN. L. REV. 367, 408-12 (1985).

64. JACKSON, supra note 63 at 4-5. See also Harold Hongju Koh, The Globalization of Freedom, 26 YALE J. INT'L L. 305, 306 (2001) (discussing the body of transnational law, including human rights law, that is neither national or international in origin).

65. See e.g., Anne-Marie Slaughter, A Global Community of Courts, 44 HaRv. INT.'L L.J. (2003); ANDRÉ NoliKaEmper, NATIONAL COURTS AND THE INTERNATIONAL RULE OF LAW 12, 301 (2011); Benvenisti \& Downs, supra note 8. 
however, it is observable that rights assume far-reaching jus-generative status beneath the threshold of what is normally identified as public or specifically constitutional law: rights, in other words, also act spontaneously to form a transnational subpolitical constitution. At one level, this tendency has been identified in the proliferation of singular private rights in most national societies. ${ }^{66}$ It has been widely noted that norms arising from private litigation over personal rights increasingly elaborate a rights fabric, which imposes quite strict and increasingly uniform limits on acts of political legislation and gives potent normative structure to social interactions in different parts of transnational society. ${ }^{67}$ The production of rights-based norms through private litigation is sustained and authorized on the basis of powerful supra- or transnational presumptions in favor of singular rights. ${ }^{68}$ Yet private litigation also acts in itself as a spontaneous source of quasi-constitutional norms, able at once to curtail the scope of direct state prerogative and expand informal and semi-private patterns of normative orientation through society. International directives in respect of human rights mean that private-legal cases concerning trade, freedom of contract, migration, and mobility of labor have the capacity to articulate and solidify a powerful rights structure in relative independence of national governments and judiciaries. Such cases exemplify the spontaneous and pluralistic constitutionalization of transnational society. ${ }^{69}$ In this regard, even judicial actors with highly

66. See, e.g., Charles R. EPP, The Rights Revolution: LaWYers, Activists, AND Supreme Courts In Comparative Perspective (1998); Samuel Walker, The Rights REVOLUTION: RIGHTS AND COMMUNITY IN MODERN AMERICA (1998).

67. See for recent discussion Gralf-Peter Callies \& PeEr Zumbansen, Rough Consensus and Running Code: A Theory of Transnational Private law 75, 166-68, 243 (2010). Elsewhere, we even read that, increasingly: "Private law performs a state-breaking function." See Daniela Caruso, Private Law and State-Making in the Age of Globalization, 39 INT'L. L. \& PoLITICS 3 (2006).

68. See Aharon Barak, Constitutional Human Rights and Private Law, in HUMAN RIGHTS IN PRIVATE LAW 28 (Daniel Friedman \& Daphne Barak-Erez, eds, 2001); MoRITZ VON UNGER, MENSChENRECHTE ALs TRANSNATIONALES PRIVATRECHT 28, 126 (2008).

69. For diverse analysis of this in different contexts, see Karen J. Alter, Private Litigants and the New International Courts, 39 COMP. PoL. STUD. 22 (2006); David Jacobson, New Border Customs: Migration and the Changing Role of the State, 3 UCLA J. INT'L L. \& FoREIGN AFF, 443 (1999). On this phenomenon in the European Union, see R. DANIEL KELEMEN, The EU Rights Revolution: Adversarial Legalism and European Integration, in 6 THE STATE OF THE EUROPEAN UNION: LAW, POLITICS, AND SOCIETY 221 (Tanja A. Börzel \& Rachel A. Cichowski eds., 2003); R. Daniel Kelemen, Suing for Europe: Adversarial Legalism and European Governance, 39 COMP. POL. STUD. 101 (2006); Stephan Wernicke, Au nom de qui? The European Court of Justice Between Member States, Civil Society and Union Citizens, 13 EUR. L.J. 380 (2007). For a source clearly sharing my view that reference to rights create flexible instruments for lawmaking and 
derivative authority assume primary legislative power to establish normative structures and to provide legal cohesion across the limits dividing originally geographically fixed jurisdictions. ${ }^{70}$ It has been tellingly noted in such instances that private litigation has notable importance in producing or strengthening quasi-constitutional forms in settings of weakly-centered political-systemic authority, in which rights generated through litigation compensate for low state density and high institutional fragmentation..$^{71}$

In conjunction with this tendency, we can discern a further sub-political process of constitutional formation, in which rights have assumed effective and highly abstracted jus-generative status in transnational society. Specifically, this process of spontaneous constitutionalization is induced by the fact that the transnational political arena is increasingly populated by persons and organizations, such as nonstate actors, nongovernmental organizations (NGOs), private governance bodies, and even private regulators and standard setters, which at times utilize reference to rights to assume a position in the margins of governmental process, from which they exercise a bundle of de facto political and legislative powers. ${ }^{72}$ Such organizations explain

legal inclusion, especially in weakly unified polities, see KELEMEN, EUROLEGALISM, supra note 53 , at 236 .

70. One excellent work on these questions argues that courts addressing "transnational human rights jurisprudence" are "national and international courts at the same time," and they generate a legal order whose inclusionary functions are necessarily geographically disembedded. See VON UNGER, supra note 68, at 155.

71. See Robert A. Kagan, AdVErSarial Legalism: The AMERICAN Way of LAW 51 (2001); Robert A. Kagan, Should Europe Worry about Adversarial Legalism?, 17 Ox. J. LEGAL STUD. 165 (1997) (U.K.). This argument assumes particular salience in R. Daniel Kelemen, American-Style Adversarial Legalism and the European Union (Eur. U. Inst., Working Papers RSCAS 2008/37, 2008); R. Daniel Kelemen, The Strength of Weak States: Adversarial Legalism in the US and the EU (April 23, 2009) (unpublished paper presented at European Union Studies Association 11th Biennial International Conference) available at www.unc.edu/euce/eusa2009/papers/kelemen_10B.pdf. See also Robert Wai, Transnational Private Law and Private Ordering in a Contested Global Society, 46 HARV. INT'L L.J. 471, 479 (2005) (discussing the advantage of transnational private law).

72. One prominent observer states simply: "The principles of human rights are a major source of legitimation for claims by non-state groups." See Benedict Kingsbury, Claims by Non-State Groups in International Law, 25 CoRNELL INT'L L.J. 494 (1992). NGOs are the most important legislative actors outside strictly constructed governmental institutions. For analysis of the legislative power of NGOs, see Peter J. Spiro, New Global Communities: Nongovernmental Organizations in International Decision Making Institutions, 18 WASHINGTON Q. 48 (1995); Peter J. Spiro, Globalization, International Law, and the Academy, 32 N.Y.U. J. INT'L L. 572 (2000). On this general point, see Isabelle Gunning, Modernizing Customary International Law: The Challenge of Human Rights, 31 VA. J. INT'L. L. (1991). For emphatic accounts of the positive status of nonstate and nongovernmental actors under international law, see Jordan J. Paust, Nonstate Actor Participation in International Law and the Pretense of Exclusion, 51 VA. J. INT'L. L. 978 
their functions and mandates in reference to transnationally consolidated rights norms, and, to bolster their influence and perceived legitimacy, they increasingly submit their activities in national spheres of operation to effective judicial review by national courts. ${ }^{73}$ Where they are capable of defining their operations as consonant with inter- or transnational norms, these organizations assume authority to constrain political decisions, to assume distinct and far-reaching governance functions, to stimulate lawmaking initiatives, and even-effectively-to make the law in the particular sphere of practice to which they refer. ${ }^{74}$ In this respect, rights facilitate an informal process of constitutional elaboration, in which the essential institutional fiber of statehood is spontaneously reconfigured, and private actors are fluidly incorporated in the most essential functions of the political system.

In each of these dimensions, political and subpolitical, recent years have seen the emergence of a new model of transnational constitutional normativity. Effective constitutional norms underpinning acts of law are produced without reference to sources of agency that are located categorically outside the law, and norms with constitutional rank are

(2011); Julie Mertus, Considering Nonstate Actors in the New Millennium: Toward Expanded Participation in Norm Generation and Norm Application, 32 N.Y.U. J. INT'L. L. \& POL. 540 (2000); Peer Zumbansen, Die vergangene Zukunft des Völkerrechts, 34 KRITISCHE JUSTIZ 59 (2001). Notably, NGOs are permitted to assume important quasi-governmental and regulatory roles under certain Human Rights Conventions, in particular under the African Convention and the Inter-American Human Rights system. On the constitutional connection between NGO lawmaking and Human Rights norms in the African Court of Human Rights see Frans Viljoen, A Human Rights Court for Africa, and Africans, 30 BROOK J. INTERNAT'L L. 37, 54 (2004-2005). On the status of NGOs under the Inter-American Court see Karsten Nowrot, Legal Consequences of Globalization: The Status of Non-Governmental Organizations under International Law, 6 IND. J. GLOBAL LEGAL STUD. 592, 579-645 (1999). On the consultative status of NGOs in the UN Human Rights system see Thomas Buergenthal, The U.N. Human Rights Committee, 5 Max PLANCK Y.B.U.N.L. 352 (2001). On other participants shaping the emergence of the "transnational legal field," see Sigrid Quack, Legal Professionals and Transnational LawMaking: A Case of Distributed Agency, 14 ORGANIZATION 645, 650, 655 (2007).

73. By this, I wish to propose that courts applying rights are able at once to regulate acts of private bodies and to create a normative system that enables these bodies to assume public functions. I found varying but illuminating commentary on this phenomenon in Eyal Benvenisti \& George Downs, National Courts Review of Transnational Private Regulation 7, 9, 13 (Tel Aviv U. L. Faculty Papers 125) (2011) (Isr.); Michael P. Vandenbergh, The Private Life of Public Law, 105 CoLUM. L. REv. 2029, 2088 (2005).

74. Frank Vibert, The Rise of the Unelected: Democracy and the New SEPARATION OF POWERS 61-62 (2007); Anne Peters, Compensatory Constitutionalism: The Function and Potential of Fundamental International Norms and Structures, 19 LEIDEN J. INT'L L. 579, 583 (2006) (U.K.); Colin Scott, Fabrizio Cafaggi \& Linda Senden, The Conceptual and Constitutional Challenge of Transnational Private Regulation, 38 J.L. \& Soc'Y 8, 11 (2011). 
authenticated in a highly autonomous, internalistic, and deeply contingent fashion. ${ }^{75}$ These norms do not emanate from, and they cannot be simply referred back to, volitionally-centered democratic actors. In many cases, even their essential status as law per se, or in the strictest sense, is open to contest. ${ }^{76}$ This transnational constitutional system widely relies on, and reproduces itself from, rights, and rights have evidently begun to articulate quasi-constitutional norms at a highly accentuated level of inner-legal abstraction, autonomy, and-above all-recursivity. 77 To an increasing degree, the transnational legal order internalizes reference to rights in order to construct normative structures and a regulatory design for society. As a result, the law is able to regenerate itself from the law alone, and rights, endlessly entered into law by law, become the generative principle for law's auto-constitution.

\section{MULTI-NORMATIVE CONSTITUTIONALISM}

The net result of these tendencies is that the rising autonomy of rights in contemporary society condenses a new pattern of transnational constitutional governance, which comprises a multi-level and highly pluralistic normative order. The broader constitutional drift from constituent power to abstracted rights is distilled most clearly in the fact that the emergent constitutional apparatus of transnational society is marked by a high degree of multi-normative spontaneity. ${ }^{78}$ The most optimistic theorists of global constitutionalism have historically followed Immanuel Kant in claiming that the growth in potency of international rights conventions is likely to engender a solid constitutional order,

75. The basic principle of classical constitutionalism is thus eroded.

76. See KLABBERS ET AL, supra note 39 at 98-99; David V. Snyder, Private Lawmaking, 64 OHIo ST. L.J. 404 (2003); Gralf-Peter Calliess \& Moritz Renner, Between Law and Social Norms: The Evolution of Global Governance, 22 RATIO JURIS 269 (2009).

77. I refer here to the (contextually unrelated) argument proposed by Armin von Bogdandy and others that the "basic principle of public law is human self-determination." On my account, the fact that in global society the law is able to authorize itself through rights means that it retains a distinct quality of publicness, even when emanating from obviously multivalent or private sources. See Armin von Bogdandy, Philipp Dann \& Matthias Goldmann, Völkerrecht als öffentliches Recht: Konturen eines rechtlichen Rahmens für Global Governance, in DIE HERAUSBILDUNG NORMATIVER ORDNUNGEN: INTERDISZIPLINÄRE PERSPEKTIVEN 228 (Rainer Forst \& Klaus Günther, eds 2011).

78. That is to say, because the political system as a whole is overwritten by rights, many actors within the system can create laws, or at least directives with law-like status. On such law, see Gunnar Folke Schuppert, The Changing Role Of The State Reflected In The Growing Importance Of Non-State Actors in Global GovernanCe AND THe Role OF NON-STATE ACTORS 222 (Gunnar Folke Schuppert, ed, 2006). 
which is close in standing, inviolability, and cohesion to the normative pyramid of classical constitutionalism. ${ }^{79}$ The intuition underlying this optimism-namely, that rights have become elements of a world constitution-can be affirmed. However, rights do not assume such constitutional status by defining or underpinning a strict legal/normative hierarchy, which clearly obligates subordinate actors. On the contrary, rights form a global constitution by acting as reproducible and systemically internalistic elements of constituent power, which articulate, in acts of quite spontaneous auto-constitution, manifold and highly pluralistic premises for transnational norm formation. ${ }^{80}$

The transnational process of pluralistic or polyarchical norm construction has been hotly debated in recent literature. ${ }^{81}$ The character of legal pluralism and the extent to which pluralism impacts different states, regions, and legal systems have not yet been consistently elucidated. ${ }^{82}$ Moreover, the phenomenon of legal pluralism, both in law

79. The most extreme version of this view suggests that there exists a hierarchy of international laws, some possessing erga omnes effect. As a result, national states are constituted subjects in a constitution of international law, and they cannot exercise powers exceeding this status. See Thomas M. Franck, The Emerging Right to Democratic Governance, 86 AM. J. INT'L L. 46 (1992). For a general cross section of the global-constitutionalist literature, see HöFFE, supra note 2; Pierre-Marie Dupuy, The Constitutional Dimension of the Charter of the United Nations Revisited, 1 MAX PLANCK Y.B.U.N.L. 1 (1997) (Ger.); Bardo Fassbender, The United Nations Charter as Constitution of the International Community, 36 Colum. J. TRANSNAT'L. L. 529 (1998); Louis Henkin, Human Rights and State "Sovereignty," 25 GA. J. INT'L \& COMP. L. 31, 39-41 (1995); Stefan Kadelbach \& Thomas Kleinlein, International Law-A Constitution for Mankind? An Attempt at a Re-appraisal with an Analysis of Constitutional Principles, 50 GER. Y.B. INT'L L. 303 (2007) (Ger.); Alec Stone Sweet, A Cosmopolitan Legal Order: Constitutional Pluralism and Rights Adjudication in Europe, 1 GLoBAL CoNSTITUTIONALISM 53 (2012) (Ger.). See also Habermas, supra note 2. For a nuanced and discerning approach, see Anne Peters, Global Constitutionalism in a Nutshell, in WELTINNENRECHT: LIBER AMICORUM Jost DelbRÜCK 535 (Klaus Dicke et al. eds., 2005) (Ger.); Ernst-Ulrich Petersmann, Human Rights and International Economic Law in the 21st Century: The Need to Clarify Their Interrelationships, 4 J. INT'L ECON. L. 3, 22 (2001).

80. This multiple inclusionary dimension to rights-based legal norms was already intuited in a groundbreaking article on the integrative functions of rights in the USA. See Talcott Parsons, Full Citizenship for the Negro American? A Sociological Problem, 94 DAEDALUS 1015 (1965).

81. See my survey of this in Chris Thornhill, National Sovereignty and the Constitution of Transnational Law: A Sociological Approach to a Classical Antinomy, 3 TRANSNAT'L LEG. THEORY 394-414 (2012).

82. See KRISCH, supra note 2, at 31; Paul Schiff Berman, Global Legal Pluralism, $80 \mathrm{~S}$. CAL. L. REV. 1155 (2007); Alec Stone Sweet, Constitutionalism, Legal Pluralism, and International Regimes, 16 IND. J. GLOBAL LEGAL STUD. 621 (2009); Neil Walker, Constitutionalism and Pluralism in Global Context (RECON Online Working Paper No. 3, 
and in governance, has proved easiest to discern and to categorize in the context of limited pluralism: for example in transnational quasi-polities, such as the European Union, whose pluralism remains institutionally circumscribed. ${ }^{83}$ Broadly, however, two transnational tendencies towards legal pluralization can be identified. Both of these tendencies are defined and impelled by the growing inner-legal abstraction of rights, and in both tendencies rights and courts applying rights again assume an effective auto-constituent status for transnational legal order.

To illustrate these claims, first, rights shape a pluralistic or multi-normative transnational constitution by solidifying an emergent arena of inter- or transnational norms, which, in ways considered above, enunciate principles and procedures that block certain, and create constraints for other, sovereign-democratic legislative practices. In this respect, the transnational constitution derives its structure from the layering of national and inter- or transnational legal sources. One outcome of this is that national courts appear as the "second layer" of a transnational judicial hierarchy, ${ }^{84}$ and, in their capacity as mediators between inter- or transnational and national normative orders, courts utilize rights to build a suspended normative structure that decisively preempts, shapes, and underscores legislation. ${ }^{85}$ Interpretation of laws

2010); Neil Walker, Taking Constitutionalism Beyond the State, 56 POL. STUD. 519 (2008) (U.K.).

83. See, e.g., Poul F. KJaer, Between Governing And Governance: On the Emergence, Function and Form of EURope's Post-National Constellation 141 (2010); Christian Joerges, Constitutionalism and Transnational Governance: Exploring a Magic Triangle, in TRANSNATIONAL GOVERNANCE AND CONSTITUTIONALISM 339 (Christian Joerges et al. eds., 2004); Kaarlo Tuori, The Many Constitutions of Europe, in THE MANY CONSTTTUTIONS of EUROPE 3 (Kaarlo Tuori \& Suvi Sankari eds., 2010) (discussing constitutional pluralities); Christian Joerges, 'Deliberative Supranationalism-Two Defences, 8 Eur. L.J. 133 (2002); John Erik Fossum \& Agustín José Menéndez, The Theory of Constitutional Synthesis: A Constitutional Theory for a Democratic European Union (RECON Online, Working Paper 25, 2010); Karl-Heinz Ladeur, Globalization and the Conversion of Democracy to Polycentric Networks: Can Democracy Survive the End of the Nation State? (Eur. U. Inst., Working Paper No. 4, 2003) available at http://cadmus. eui.eu/bitstream/handle/1814/199/law03-4.pdf; Christian Joerges, How the Rule of Law Might Survive the European Turn to Governance 14 (May 31, 2007) (unpublished paper presented at NEWGOV Consortium Conference Project no. CIT1-CT-2004-506392) available at $\mathrm{http} / / / \mathrm{www}$.eu-newgov.org/database/PUBLIC/NEWGOV_CC2007-Contributio n_Joerges.pdf.

84. Moritz Renner, Towards a Hierarchy of Norms in Transnational Law?, 26 J. INT'L ARB. 533, 554 (2009).

85. This point is made in Charles F. Sabel \& Oliver Gerstenberg, Constitutionalising an Overlapping Consensus: The ECJ and the Emergence of a Coordinate Constitutional Order, 16 EUR. L.J. 511 (2010). See also Walter Mattli \& Anne-Marie Slaughter, Revisiting the European Court of Justice, 52 INT'L ORG. 177, 204 (1998). On courts utilizing rights to 
by different courts establishes a recursive foundation for constitutional order, in which acts of constitutional foundation, statutory legislation, and judicial interpretation cannot be strictly separated or distinctly classified. ${ }^{86}$ This aspect of the transnational constitution is marked by vertical or multilevel pluralism.

One further outcome of this first tendency, however, is that different judicial actors (both national and inter- or transnational) contest supreme jurisdictional power with one another, and many sources of judicial authority are forced to exist side by side, such that their relative rank or standing are uncertain. ${ }^{87}$ Courts (both international and national), have central importance in connecting one level of the national/international polyarchical regime to another, and they routinely act as nodal points, translating international norms into directives for national policy. However, courts themselves perform this function in a polyarchical fashion: the bounds of competence for different courts are often unclear and conflicting and do not cement a clear hierarchy of norms. ${ }^{88}$ This aspect of the transnational constitution is marked by horizontal or multifocal pluralism.

For each of these reasons, national states increasingly operate as one group of actors within a highly pluralistic landscape of transnationally consolidated and overarching constitutional norms, and the legislative functions of national states are constitutionally determined by (often rival and overlapping) vertical and horizontal normative forces. This gives rise to an intensely pluralistic constitutional landscape, in which legal norms, no longer reducible to evidently acceded democratic mandates, produce a clearly autonomous, yet also only disputably obligatory, set of constraints for national institutions.

cement their own quasi-constituent power, see Elina Paunio, Conflict, Power, and Understanding-Judicial Dialogue between the ECJ and National Courts, 7 No FOUNDATIONS 5, 20 (2010) (Fin).

86. See Oliver Gerstenberg, Expanding the Constitution Beyond the Court: The Case of Euro-Constitutionalism, 8 EUR. L.J. 172, 190 (2002).

87. For excellent discussion, see Nico Krisch, The Open Architecture of European Human Rights Law, 71 MODERN L. REV. 183, 184-85 (2008).

88. See Carl Lebeck, The European Court of Human Rights on the Relation Between the ECHR and EC-Law: The Limits of Constitutionalisation of Public International Law, 62 ZEITSCHRIFT FÜR ÖFFENTLICHES RECHT 195, 217 (2007) (Ger.). See generally Miguel Poiares Maduro, Courts and Pluralism: Essay on a Theory of Judicial Adjudication in the Context of Legal and Constitutional Pluralism, in RULING THE WORLD?: ConsTITUTIONALISM, INTERNATIONAL LAW, AND GLOBAL GOVERNANCE, supra note 39, at 356; Miguel Poiares Maduro, Interpreting European Law: Judicial Adjudication in a Context of Constitutional Pluralism, (IE Law Sch., Working Paper No. WPLS08-02, 2008) (examining the role of the Court of Justice in the context of constitutional pluralism) available at http://ssrn.com /abstract $=1134503$. 
Second, rights shape a multi-normative transnational constitution by virtue of the fact that, across the sectorial divides in transnational society, they create a secondary, less formal constitutional apparatus, which also permits, reflects, and reinforces a fragmentation of the jurisdictional power and normative monopoly vested in national-democratic legislatures. In this respect, the pluralistic layering of private and public legal sources give rise to the transnational constitution. This constitution may come into being in one of many ways. For example, this constitution may be formed through litigation over private rights: in particular, it may be created by judicial controversy, in which private litigation in national courts entails the invocation of international norms to support rulings, such that transnational expectations in respect of rights assume horizontal constitutional power (i.e. through third-party effect) in, and through, courtrooms. ${ }^{89}$ This constitution may also be constructed through the spontaneous constitutionalization of functional sectors outside the state, either through the growing power of private/corporate actors to specify rights establishing binding norms for their relevant spheres of exchange, or through the use of rights norms borrowed from judicial institutions to enable the amalgamated hybridization of private and public authority. ${ }^{90}$ Moreover, this constitution may be produced through the status of rights as institutions that act normatively to unify distinct realms of formally private social practice, running laterally across national boundaries. ${ }^{91}$ An example of this might be found in media law where international service providers accept formative guidance by international rights standards to increasingly promote a constitution,

89. See Francisco Forrest Martin, Challenging Human Rights Violations: USING INTERNATIONAL LAW IN U.S. COURTS 39, 45-46, 56, 250 (2001). For studies of ways in which such processes assume impact even in polities traditionally resistant to international normative directives, see Luisa Antoniolli, Taking Legal Pluralism Seriously: The Alien Tort Claims Act and the Role of International Law Before U.S. Federal Courts, 12 IND. J. GLOBAL LEGAL STUD. 651 (2005); Jeffrey M. Blum \& Ralph G. Steinhardt, Federal Jurisdiction over International Human Rights Claims: The Alien Tort Claims Act After Filartiga v. Peña-Irala, 22 HARv. INT'L J.L. 53, 57 (1981).

90. See Christoph Engel, A Constitutional Framework for Private Governance, 5 GERMAN L.J. 197, 233 (2004); Christoph Engel, Hybrid Governance across National Jurisdictions as a Challenge to Constitutional Law, 2 EUR. BUS. ORG. L. REV. 569, 583 (2001) (U.K.); Kalypso Nicolaidis \& Gregory Schafer, Transnational Mutual Recognition Regimes: Governance Without Global Government, 68 L. \& CONTEMP. PROBS. 263, 302 (2004); Vandenbergh, supra note 73 , at 2039. Centrally, see GUNNAR FOLKE SCHUPPERT, GOVERNANCE UND RECHTSETZUNG. GrundFragen EINER MODERNEN REGELUNGSWIRTSCHAFT [GovERNANCE and Regulation. Fundamental Questions of Modern Economic RegUlation] 386 (2011) (Ger.).

91. See the general claims in GunTHER Teubner, COnstitutional Fragments: Societal Constitutionalism AND Globalization (2012). 
focused solely on media, which overarches national boundaries, and which may, in some cases, conflict with national constitutional norms. ${ }^{92}$ A further example may be found in medicine, where medical suppliers increasingly construct a transnational normative order focused solely on medicine that is able to constrain national state authority by enacting and promoting international human-rights standards in respect of medical provision. ${ }^{93}$ All such cases can legitimately be seen as constitutional processes, in which rights offer functionally localized constituent power to diverse social actors and organizations.

In all such instances, a legal order is reinforced, in which expectations regarding rights perform functions traditionally accorded to constituent actors. This creates a diffuse, functionally localized, and informal constitution, which relies on, and recursively reproduces, autonomously constructed rights. Indeed, this informal constitution is founded through reference to rights as ultra-contingent and auto-constituted sources of constituent norm formation. ${ }^{94}$

To conclude, in the different dimensions of the transnational constitution, a condition of extreme, simultaneously geographical, sectorial, and functional polyarchy is increasingly identifiable. This polyarchical constitution lacks firm societal or volitional foundations. However, at each of its levels, it obtains some degree of internally inclusionary cohesion because courts, other judicial actors, and private agents recognize and apply rights as structural points of orientation. These actors also recognize that justiciable rights are claimed by, and allocated to, private agents in society, and that rights are cemented as the basis for policy-making both by private and by public bodies. The emergence of a global system of governance is underpinned by a

92. Consider recent controversies attached to Google in China. Consider also the Australian High Court ruling in Dow Jones \& Co v. Gutnick (2002), in which, albeit without final success, human rights agreements were considered as instruments for providing a common standard for transnational disputes regarding the potentially defamatory content of Internet sites.

93. See, e.g., Gunther Teubner, Die anonyme Matrix: $Z u$ Menschenrechtsverletzungen durch "Private" Thansnationale Akteure [The Anonymous Matrix: On Violations of Human Rights by "Private" Transnational Actors] 44 DER STAAT. ZEITSCHRIFT' FÜR STAATSLEHRE UND VERFASSUNGSGESCHICHTE, DEUTSCHES UND EUROPÄISCHES ÖFFENTLICHES RECHT [THE STATE. JOURNAL OF POLITICAL SCIENCE AND CONSTTTUTTONAL HISTORY, GERMAN AND EUROPEAN PUBLIC LAW] 161 (2006) (discussing whether fundamental rights not only obligate States, but also private transnational actors) (Ger.).

94. For Teubner, rights have no structural or normative cause, and they draw content solely from contingent acts of law's "self-production" and "self-control." See Gunther Teubner, Globale Zivilverfassungen: Alternativen zur staatszentrierten Verfassungstheorie [Global Civil Constitutions: Alternatives to a State-Centric Constitutional Theory], in STAATSVERSTÄNDNISSE [CONCEPTIONS OF STATE] at 117, 139 (Rüdiger Voigt, Vol. 11, 2007) (Ger.). 
proliferation of rights, occurring both at different governmental levels and as attached to private agents. ${ }^{95}$ That is to say, rights connect the national to the inter- or transnational dimension of global order: they do this mainly through the intermediary functions of courts. Further, however, rights connect the public to the private dimension of global order: they do this mainly through the ability of courts to provide a normative structure to regulate private activities, and through the fact that private bodies can assume governance functions if they show compliance with rights expectations. In this latter respect, rights make it possible for political institutions selectively to incorporate private actors without forfeiting their normative public structure. ${ }^{96}$ In short, rights are transferred from one level of the global governance order to another, and they form the recursive constitutional foundation for its (always precarious) cohesion and extension. The ability of different layers of the governance apparatus to obtain support in and to effectively vindicate rights provides structure and orientation for the global governance regime in its totality, ${ }^{97}$ and rights form the underlying reference for a highly disparate set of constitutional forms, each of which solidifies normative order in a highly pluralistic and politically uncentered fashion.

\section{A FunCtional ANALYsis of NeW Constitutionalism}

In each of its dimensions, the emergent constitutional form of contemporary society reflects, at a surface level, a dramatic transformation of conventional constitutional functions. Evidently, the contemporary constitution exists independently of singular democratic mandates or acts of legislation, and it is defined by the fact that judicially enforced rights provide a highly detached, cross-boundary normative substructure both for primary acts of polity building and for specific acts of legislation and regulation. ${ }^{98}$ Similarly, at a more substructural level, this constitution performs multiple functions of normative inclusion, each at a high degree of spontaneity, uncertainty, and contingency, and it applies rights to authorize legislation in an extremely iterable, internal, and abstracted manner. In both respects,

95. See Charles F. Sabel \& Jonathan Zeitlin, Learning from Difference: The New Architecture of Experimentalist Governance in the EU, 14 EUR. L.J. 271 (2008).

96. See Vandenbergh, supra note 73 , at 2090.

97. See Joshua Cohen \& Charles F. Sabel, Global Democracy?, 37 N.Y.U. J. INT'L L. \& PoL. 763, 795 (2006).

98. For claims in agreement see Giuseppe Martinico \& Oreste Pollicino, Between Constitutional Tolerance and Judicial Activism: the 'Specificity' of European Law, 10 EUR. J.L. REFORM 99-100 (2008). 
the contemporary constitution establishes a deeply internalistic political system, in which the original external reference of the political system, expressed in the idea of constituent power, is superseded. Rights, recursively entered and re-entered into the political system, construct a matrix for the ongoing reproduction of society's political structure in highly self-determined, highly contingent, and highly internalistic fashion.

In this respect, the emergent constitutionality of modern society reflects an inner adaptive dimension of society's self-organization, and it responds to a specific functional condition of modern society as a whole. ${ }^{99}$ In fact, the nascent constitutional form of modern global society constructs a political system that is acutely molded to the changing functional exigencies of contemporary society.100 On one hand, the generality of rights acting as surrogate or preconstituted constituent power has become most visible under conditions where political power is utilized across societal realities marked by decreasing national/geographical cohesion and uniformity, diffuse social agency, and complexly embedded, pluralistic normative claims. ${ }^{101}$ Under such conditions, political actors struggle to generate or presuppose immediate or unequivocal forms of legitimacy, and they are required to produce and authorize legislation in a rapidly iterated manner, with limited opportunity for testing or manifesting support located outside the political system. ${ }^{102}$

Against such backgrounds, however, the implementation of generalized rights as the basis for political institutions has made possible the emergence of a political system that is able to perform

99. By this, I mean that the reconstruction of the transnational political system around rights needs to be seen as a process through which the system stabilizes its functions in relation to broad shifts in its social environment-especially to the rising extension, acceleration and complexity of the environments to which law needs to be applied.

100. Such changing functional exigencies could be categorized as follows: social requirement for laws that can be extended across wide geographical and cultural distances; the need for rapidly iterable laws; the need for more laws; the need for laws that can be easily reused in multiple settings.

101. The specific link between rising judicial power is addressed critically by Ran Hirschl. See, e.g., RAN HIRSCHL, TOWARDS JURISTOCRACY: THE ORIGINS AND THE CONSEQUENCES OF THE NEW CONSTITUTIONALISM (2004). But it is also addressed in a rather more balanced sociological manner by Jacques Commaille. See for one example Jacques Commaille, The Janus Model of Legal Regulation: Changes in the Political Status of Justice, 2 RCCS ANNUAL REVIEW (2010).

102. By this, I mean that in classical (national) political systems the legitimacy of law was, at least notionally, dependent on its approval by an external constituency. In societies where law is applied rapidly and across national boundaries, however, this external constituency does not exist, and such approval is impossible to secure. The switch from constituent power to rights allows societies to adapt to this fact. 
processes of inclusion and regulation in a highly internalistic and fluidly reactive fashion. This system is in a position to positively conduct acts of legislation in a manner that is sensitive to the rapidly changing requirements for, and the growing volume of, law that is produced by contemporary society. ${ }^{103}$ In particular, the reference to rights as an auto-constituent explanation for law has allowed political actors to cement within the law abstract normative foundations for relatively secure legislative acts, and to evade the incessant need to produce quantities of external/volitional legitimacy to sustain each act of legislation. By internalizing a potent reference to rights, a transnational political system (incorporating states and other political actors) has evolved that is able to store, and to accompany its power with, simple forms of internal legitimacy whilst responding to complex societal demands for multiple, contingent, and rapidly changing normative inclusion and legislation. This means that the political system can manufacture and multiply its power across society without direct reliance on external supports or sources of legitimacy. This also means that, as power is applied to designated bearers of rights, the classical self-limiting function of constitutional norms is preserved, and the political system occludes itself against uncontrollable conflation with other spheres of practice and exchange. In both respects, rights have promoted a multi-leveled abstraction of inclusionary power as an alternative to conventionally centered (national) polities. They have made it possible for societies to translate reserves of power originally attached to distinct and clearly identifiable constituent actors into a societally abstracted medium, applied across society at a high level of internal autonomy, transnational inclusivity, and functional specificity.

The rising prominence of political rights in the transnational constitution can thus be explained from a socio-functional perspective. Actors within the political system now show increasing dependence on rights as a norm to underwrite power: reference to rights means that political actors can more easily respond to demands for multiple and complex inclusion, and they utilize rights to construct reserves of political power marked by substantial inner abstraction and structural autonomy. This growth in the autonomy of law (through rights) is

103. The rising demand for law is specifically a feature of national societies whose intersection with global society is widening. See my preliminary discussion of the case of Russia in Chris Thornhill, National Sovereignty and the Constitution of Transnational Law: A Sociological Approach to a Classical Antinomy, 3 TRANSNAT'L LEGAL THEORY 446 (2012). For similar processes in Brazil, see Maria Angela Jardim de Santa Cruz Oliveira, Reforming the Brazilian Supreme Federal Court: A Comparative Approach 99 WASH. UNIV. GLOBAL STUD. L. REv. 1010 (2006). But the escalating need for law can be observed quite generally as a characteristic of globalized society, and this need underlies the growth in complex and informal modes of lawmaking identified above. 
induced by the fact that - to an increasing degree-the law is needed for extremely variable patterns of inclusion. It is applied across very divergent transnational societal environments, and its ability to presuppose any original or external identity between itself and its objects or addressees is restricted. Moreover, it is induced by the fact that society, in its rising transnational complexity, needs a constantly escalating amount of law. In this reality, rights assume structurally augmented significance for the legal and political system of global society. They play a vital role in enabling the legal transmission of power across society, and they multiply the capacities for lawmaking possessed by a society as a whole. The transnational constitution applies rights to validate the use of power and law specifically because the existence of a simple democratic mandate, or even a firmly legitimated institutional structure, for power's exercise cannot be presupposed, and the growing inclusion of objects (persons) under law needs to be undertaken across precarious and acentric environments, in an internally flexible and normatively self-referential fashion. As discussed above, rights enable the law to internalize a stable normative account of its authority, to construct an internal (auto-constituted) image of its constituent author, and to internally iterate a justification for itself across widening and increasingly diverse social terrains. In this respect, the auto-constituent force of rights has proved functionally essential to the expansionary reproduction both of political power and of law in contemporary society.

On this basis, we can conclude that rights have begun to express an effective code for the emergent transnational political system. That is to say, where contemporary society encounters a requirement for institution building and political structure, it expresses this requirement through reference to rights, and it cements norms for spontaneous institutional formation by explaining institutions as authorized by rights. The rights/not-rights dichotomy becomes the recursively auto-constituent device by which a society distinguishes those exchanges that require political regulation from those that do not, and rights form a functional language which allows society to translate certain events, subjects and phenomena into a register that is immediately recognized as intelligible to the political system.

To be sure, spheres of functional interaction located outside politics (in the strict sense) also avail themselves of rights as instruments of systemic self-organization. For instance, exchanges in medicine refer to rights, which are not necessarily or intrinsically political; the same applies to exchanges in art, science, education, religion, intimate 
relationships, and so on. ${ }^{104}$ Indeed, in such cases, societal exchanges are likely to phrase themselves in reference to rights in order to specifically ensure that they are not exposed to political control. ${ }^{105}$ Rights in religion, love, art, or education reduce the contamination of such exchanges with characteristic political contents. This is the general function of private rights as principles that uphold the complexly differentiated fabric of society in its totality, and in fact specifically depoliticize many societal exchanges. ${ }^{106}$ Yet, the reference to rights in medicine, science, art, family, intimate life, or in any other areas of social relations, does not only reflect the differentiation of such exchanges from politics. On the contrary, the reference to rights can also be perceived as reflecting an intrinsic interface between any given social system and politics, and, in each sphere of practice, rights commonly describe the exchanges throughout society which have a particular susceptibility to become political. ${ }^{107}$ Rights instill a residual political structure in society, through reference to which the political system can

104. Regarding rights as inner dimensions of an emergent constitution of the medical or healthcare system, one commentator examines the production of medical rights in the following terms: "The practice of informed consent in the clinical arena evolved primarily through the medical profession's responses to various decisions by the courts (establishing civil and criminal liability for unauthorised medical interventions), but in some legal systems it has now, together with the right to bodily inviolability, gained the status of a fundamental right. Due to the link to principle of autonomy, dignity, and the human rights discourse, that practice began to be perceived as a paradigm of medical ethics and it now penetrates human rights instruments concerning biomedicine and bioethics and relevant documents of medical practice, including the Council of Europe Convention on Human Rights and Biomedicine (i.e. the Oviedo Convention) together with its Additional Protocols, UNESCO Declarations on the Human Genome and Human Rights (1997), Human Genetic Data (2003), and Bioethics and Human Rights (2005), the Ethical Principles for Medical Research Involving Human Subjects were established by the Nuremberg Code in 1947, and further developed in the subsequent WMA Declaration of Helsinki." See Atina Krajewska, Global Health on its Way to Self-Constitutionalisation: Towards a Comprehensive Theory of Global Health Law (unpublished MS, on file with author), preliminary version presented at University of Cardiff (December 2012).

105. The example above of an internally generated medical right would-presumably-have the outcome that exchanges regarding medicine could operate in relatively self-regulating fashion, requiring only exceptional internalization in the political system.

106. This is Luhmann's view of rights. See the seminal account of rights as institutes that trace the limits of society's politics in NIKLAS LUHMANN, GRUNDRECHTE ALS INSTITUTION: EIN BEITRAG ZUR POLITISCHEN SOZIOLOGIE [FUNDAMENTAL RIGHTS AS AN INSTITUTION: A CONTRIBUTION TO POLITICAL SOCIOLOGY] 135 (1965) (Ger.).

107. By this, I mean that rights trace a political code at that moment where they express demands for regulation which structurally presuppose the intercession of the political system in other spheres of practice. 
organize and explain its reactions and interventions. ${ }^{108}$ Medical exchanges, for instance, cease to be simply medical where they entail a conflict or infraction of rights, or where conflicts regarding the authority and legitimacy of medical practices are formulated in relation to rights. Similarly, the political bracketing of intimate relations through rights becomes its antithesis as soon as such relations are recorded as exposed to endemic rights violations or where the legitimacy of certain conventions raises controversies expressed through rights claims. The same applies to exchanges in art, science, education, and so on. ${ }^{109}$

Exchanges outside the political system articulate their requirement for political power, in short, through claims to rights and through perceived derogations of rights, and society registers a need for political-structural formation in a vocabulary provided by rights. The translation of social exchanges into the grammar of rights is the process in which a society objectively expresses its emergent political structure. In general, the reference to the rights code is a (typically submerged, but always latently constructed) societal device that makes possible the creation of relatively stable inclusionary mechanism for the use of political power that are underscored by reasonably coherent distinctions between law and nonlaw or politics and nonpolitics, under conditions where this would otherwise be impossible.

It is often observed that, in its multi-structural spontaneity, the transnational constitution of contemporary society marks a radical shift away from politically centered social order, and it builds up reserves of counter-power in which different socio-functional contexts produce highly differentiated inner normative systems. ${ }^{110}$ Arguably, however,

108. In other words, where the political system intervenes in medical exchanges, in art, in religion, it is likely to do so, either ideologically or otherwise, in the name of rights, and it is likely to articulate its exchanges through rights. This might occur positively, e.g. to guarantee rights to health or treatment in medicine. This might occur negatively or prohibitively, e.g., when political actors intervene in exchanges linked to religion owing to security concerns.

109. See the case of potential conflict between rights of privacy and rights of personal security and freedom from violation discussed in KoskENNIEMI, THE POLITICS OF INTERNATIONAL LAW, supra note 3, at 142. Such extreme conflicts regarding the primacy of one right over another would seem to create a necessity for the intervention of a third party: that is, the political system, enunciating political principles to define the relative hierarchy of contested rights.

110. See Andreas Fischer-Lescano, Luhmanns Staat und der transnationale Konstitutionalismus [Luhmanns State and Transnational Constitutionalism], in DIE STAATEN DER WELTGESELLSCHAFT. NIKLAS LUHMANNS STAATSVERSTÄNDNIS [THE STATES OF WORLD SOCIETY. NIKLAS LUHMANN'S CONCEPTION OF THE STATE] 99, 109 (Marcelo Neves \& Rüdiger Voigt eds., 2007) (Ger.) (analyzing the development of a global constitutional pluralism which can not be traced back to international law or politics but must rather be understood as transnational). 
the converse is the case. Through its concentration around rights, the transnational constitution develops as a multi-faceted instrument for irrigating power and for solidifying distinctive reserves of legal/political power through a weakly structured society. Indeed, reference to the rights code enables society spontaneously to designate certain exchanges as political, and, accordingly, to build reactive political structures. Rights thus act, ex nihilo, as the founding principle for the politicality of today's deeply acentric society. Moreover, the reference to the rights code enables this society to meet its demands for the application of political power in a highly improvised and spontaneous, yet also consistent and internally authorized fashion. To this degree, the reference to rights as the founding principle of law's authority enables the political system to generate more power in order to cover its exchanges through society, and it allows it to transmit this power in highly recursive fashion. Expressed differently, whereas under classical constitutional doctrine the political system was based in one decision, and it was obliged to refer to this decision for its authority, the modern transnational constitutional system, founded in a fluid rights code, is able to multiply its decisions in a process of rapid internal iteration, and, by promoting rights as the foundation of law's authority, it can quickly apply law to emergent conflicts and regulatory demands.111 Underlying all the processes described above is the fact that modern societies encounter and endlessly stimulate a need for more law to address the complex and ultra-interdependent objects for legislation that they encounter and engender. This need cannot be satisfied through traditional techniques for mobilizing consensus, support, or even resources of legitimacy positioned externally to the political system. The modern political system is obliged to promote highly internalistic reserves of legitimacy (based in rights), and the resultant rights-based judicialization of political decision-making enables the political system, to some degree, to extend its reserves of power, and to generate a volume of legislation adequate to exponentially rising societal expectations. ${ }^{112}$

111. For a theory of the decision as paradigmatic for the conditions of contingency in modern society, see Michael Th. Greven, Die Politische Geselluschaft. Kontingenz und Dezision als Probleme des Regierens und DeR Demokratie [The Political Society. Contingency and Decision as PRoblems of GovernancE AND Demockacy] 14 (1999) (Ger.).

112. This is observable as a general phenomenon. But it is a particular feature of societies in transition from authoritarian to rights-based constitutions that the reference to rights (and ensuing potentials for litigation) makes it possible for them rapidly to expand their capacities for producing law. For examples see Egardo Buscaglia, Corruption and Judicial Reform in Latin America, 17 PoL. STUD. 273, 275 (1996); Kevin J. O'Brien \& Lianjiang Li, Suing the Local State: Administrative Litigation in Rural China, 51 THE 


\section{Post-Classical or NEo-Classical Constitutionalism?}

The constitutionality of contemporary society is typically contrasted in profound fashion with common ideas of classical constitutionalism, which define constitutional norms as sources of legal-political "countervailance": that is, as a corpus of laws acting to constrain the power of sovereign states. ${ }^{113}$ Apart from purely normative constructions of the constitution, which see contemporary global norms as replicating original models of national order, ${ }^{114}$ the perception of the constitutional uniqueness of contemporary society unifies all (otherwise disparate) examinations of the status and content of the emergent global or transnational constitutional order. From the perspective outlined above, however, it is only a rather superficial approach to constitutions, which insists on the presence of a radical breach between the inner form of the transnational constitution and earlier, more classical constitutionalist designs. In fact, the growth of abstracted constitutional rights as primary components of contemporary transnational political order can easily be seen to reflect a more general logic of constitutional governance. If approached from a functionalistic perspective, the emergent transnational constitution gives strong manifest expression to certain potentials that were always implicit in constitutional forms. Indeed, it is arguable that the global form of the contemporary constitution was already, albeit in submerged fashion, functionally co-implied in the classical form of the national constitution.

To illustrate this, if we look beneath the literal self-reflection of classical constitutionalism, we can see certain deep functional continuities between contemporary and classical constitutional models.

In the first instance, for example, if detached from their literal normative construction, classical constitutions clearly acted as instruments in society in which the legal/political system was able to underwrite and authorize its own abstraction, and the normative elements of classical constitutions played a vital adaptive role in enabling the modern political system to utilize and transmit its power in

CHINA J. 75, 86 (2004). As discussed above, it is generally noted that rights allow courts to assume legislative functions.

113. See ScotT Gordon, ConTrolling the State: Constitutionalism From ANCIENT ATHENS TO TODAY 16 (2002). For discussion of a constitution as "limited power" see ANDRÁs SAJó, LIMITING GOVERNMENT. AN INTRODUCTION To CONSTITUTIONALISM 2 (1999).

114. Mauro Cappelletti, Nécessité et Légitimité de la Justice Constitutionnelle [Necesssity and Legitimacy of Constitutional Justice], 33 ReVUE INTERNATIONALE DE DroIT COMPARÉ [INT'L J. COMP. L.] 625 (1981) (Fr.). 
a flexibly positive fashion. ${ }^{115}$ The characteristic internalism or auto-constitutionality of the contemporary constitution was in fact visibly anticipated by classical constitutions. Classical constitutions were designed quite specifically as institutions that formed a legal/political order able to authenticate itself without relying on external actors and singular sources of external legitimacy, such that they were able to reproduce political structures across society at a high degree of autonomy. Indeed, this was already evident in the classical doctrine of constituent power, which purported to found the legal/political system in radically external acts of norm-giving volition. The original doctrine of constituent power, proclaiming the origin of law's legitimacy as external to the political system, always masked the fact that the political system utilized this principle, through its filtration through rights, to detach itself from external agency, and to regenerate its power by supplying a recursive internal authorization for its functions. The principle of the external relation between constituent power and the state is deeply interwoven in the Rousseauian self-explanation of modern democratic society as characterized by collective self-legislation. ${ }^{116}$ Yet, the externality of constituent power was always, dialectically, an internality, and the concept of constituent power always formed a projection, through which the emergent modern political system could imagine itself as externally authorized while in fact excluding external agents (the people) as originating sources of law. Constituent power instilled an idea of external legitimacy within the political system, through reference to which the political system could autonomously - that is, internally-reproduce its power. This is clearly illustrated by the earliest theoretical discourses on constituent power. ${ }^{117}$ From its first formulation, this concept was always in itself a paradox: it was the essential foundation for a political system able to procedurally measure and restrict the factual presence of the people in government,

115. A related point--namely, that the "the principle of democracy" is a "formula of self-reference" in the political system-is made in Niklas Luhmann, Machtkreislauf und Recht in Demokratien, 2 ZEITSCHRIFT FÜR RECHTSSOZIOLOGIE, 164 (1981).

116. See generally Dieter Grimm, Gesellschaftlicher Konstitutionalismus-Eine Kompensation für den Bedeutungsschwund der Staatsverfassung? [Social Constitutionalism-A Compensation for the Vanishing Importance of the Constitution?], in STAATSRECHT UND POLITIK. FESTSCHRIFT

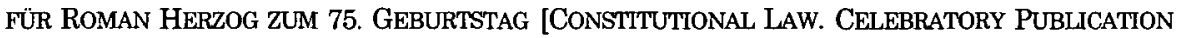
FOR ROMAN HERZOG'S 75TH BIRTHDAY] 67 (Matthias Herdegen et. al, eds., 2009) (Ger.).

117. The classical concept of constituent power invoked by Sieyès was designed at once to found a revolutionary political system, but then, immediately subsequent to its constitutional foundation, to ensure that its founders fell silent and remained outside the political system. See EMmanUel-Joseph SiEYĖs, PrÉLIMINAIRe DE LA Constitution: RECONNAISSANCE ET EXPOSITION RAISONÉE DES DROITS DE L'HOMME \& DU Citoyen [PRELIMINaRy CONSTITUTION: RECOGNITION AND REASONED EXPOSITION OF Human RIGHTS AND THE CiTIZEN] 19, 21 (1789) (Fr.). 
and so to reproduce its exchanges through society in an internally self-authorizing fashion.118 Constituent power was always a self-authorization (auto-constitution) of the political system.119 To this degree, the internalism of the contemporary political system merely makes literally explicit the paradoxical, functional subterfuges of classical constitutions.

Further, if analyzed in light of their submerged functions, it is observable that classical constitutions also sustained the autonomy of the political system via a surrogation of constituent power through rights.

This means, first, that, although classical constitutions claimed to draw legitimacy from a constituent power standing before all other legal institutions, these constitutions had their origins in a social environment in which the exercise of constituent power was inseparable from the exercise of rights. The drafting of the first modern constitutions was generally a process in which the assertion of constituent power was clearly seen as an exercise of a prior constitutional right, and constitutions were designed to give material form to rights that already existed. ${ }^{120}$ In the revolutionary United States and revolutionary France, most notably, the claim to act as constituent power was essentially coterminous with the claim to rights, and the fabric of constituent power was always suffused with and predefined by rights: constituent power was only expressed as a claim for rights, and it was in fact pre-constituted by rights. ${ }^{121}$ In the first modern

118. See Edmund S. Morgan, InVEnting The PeOPle: The Rise Of PopulaR SOVEREIGNTY IN ENGLAND AND AMERICA 148 (1989); William R. Casto, James Iredell and the American Origins of Judicial Review, 27 CONN. L. REV. 330 (1995).

119. In this regard, note the claim, regarding the assertion of constituent power in the American Revolution, that "Federalists embraced the authority of the collective sovereign as the means of establishing the Federal Constitution. Yet many were reluctant to acknowledge, much less encourage, the role of the people as the ruler." Christian G. Fritz, American Sovereigns: The PEople and america's Constitutional Tradition BEFORE THE CIVIL WAR 150-51 (2008). Note also the related observation that "For Federalists popular sovereignty was a powerful constitutional fiction. While the people possessed all sovereignty, they parceled it out among different institutions and jurisdictions." Daniel J. Hulsebosch, CONSTITUTING EMPIRE: New YORK AND THE Transformation of Constitutionalism in the ATlanTiC WorLD, 1664-1830, at 229 (2005).

120. It is argued, tellingly, that in the United States rights were presumed to have constitutional status even before the state constitutions and the federal Constitution were written. See Jordan J. Paust, On Human Rights: The Use of Human Rights Precepts in U.S. History and the Right to an Effective Remedy in Domestic Courts, 10 MICH. J. INT'L L. 571 (1989).

121. The logic of rebellion against the Stamp Act and other coercive statutes in early revolutionary America was expressed, normally through courts of law, as an attempt to protect demonstrable rights. Jack Rakove, The Super-Legality of the Constitution, or a 
constitutions, therefore, the distinction between constituent and constituted power was never clear, and constituent power always possessed an inner juridical dimension.

This means, second, that, once classical constitutions were established, constituent power remained present and configured in the constitution, not as power exercised by a factually existing people, but as power exercised by an aggregate of people qua rights holders. The entire classical doctrine of constituent power in fact implied that the people (the nation) are integrated in the political system as the people under higher law, and higher law is presided over by courts, and applied in the form of rights. ${ }^{22}$ Legislation produced by the political system is then authorized through reference to the constituent people as rights holders, standing above and prior to the factually existing electoral people, and the original will of the people is always conserved, represented, and expansively re-enacted through the rights

Federalist Critique of Bruce Ackermann's Neo-Federalism, 108 YALE L.J. 1931, 1940 (1999). Rights defended in this way already existed as elements of a formally acknowledged constitution. On this point see Mary Sarah Bilder, Idea or Practice: A Brief Historiography of Judicial Review, 20 J. POL'Y HIST. 6 (2008). The resultant logic of constituent assembly, in which claimants to rights began to found new centers of government in different British colonies, was motivated by similar principles. See AKHIL Reed Amar, The Bill Of Rights: Creation and Reconstruction 29, 122 (1998). In France, analogously, the impulse towards the revolutionary assertion of constituent power after 1789 was shaped by a widespread demand for equal juridical entitlements, abrogating the uneven, corporatistic, and highly privileged rights structure of the Ancien Régime. Although rights had less formative importance in revolutionary France than in the United States, the norm of shared and equal rights in law impelled the assault on singular and corporate legal privilege which first gave rise to the idea of republican sovereignty and constituent power in the summer months of 1789. EMMANUEL SIEYĖS, QU'EST-Ce QUE LE TIERS-ÉtaT? [What IS THE ThiRd ESTATE?] 45 (1970) (Fr.). Here too, constituent power was expressed as part of an existing (or at least imagined) rights-based constitution. See the analysis throughout in ARNAUD VERGNE, LA NOTION DE CONSTITUTION D'APRÈs LES COURS ET ASSEMBLÉEs À FA FTN DE L'ANCIEN RÉGIME [ThE IDEA OF THE CONSTITUTION ACCORDING TO THE COURTS AND ASSEMBLIES AT THE END OF THE OLD REGIME] (1750-1789) (2008) (Fr.).

122. Contrary to perceptions fostered by Carl Schmitt, there was a strong doctrine of constituent power in the American Revolution. This was tied to the belief that courts should act as guardians of a higher law (especially rights). See the argument in Thomas Tudor Tucker, Conciliatory Hints, Attempting, by a Fair State of Matters, to Remove Party Prejudice, in 2 American Political Writing During THe Founding ERA 1760-1805, at 606 (Charles S. Hyneman \& Donald S. Lutz eds., 1983). See also Hamilton's famous argument in THE FEDERALIST No. 78 (Alexander Hamilton). In France, by 1795 the doctrine of revolutionary constituent power had also assumed a pronounced judicial dimension. By the end of the Thermidorian Reaction, Sieyès argued for a constitutional jury to protect higher law against statute. In so doing, he hoped "to stabilize the polity by limiting the participatory dimension of constitutional politics." Marco Goldoni, At the Origins of Constitutional Review: Sieyès' Constitutional Jury and the Taming of Constituent Power, 32 Ox. J. LEGAL STUD. 211, 233 (2012). 
jurisprudence of the courts. ${ }^{123}$ The internalization of constituent power in the political system thus occurred primarily through rights, and rights remained a recollection in the political system of its original constituent founders, which could be endlessly invoked by both legislative and judicial actors to accompany and confer validity on acts of legislation. ${ }^{124} \mathrm{By}$ conserving an image of constituent power in rights, the political system was able to autonomously reproduce its power across society, to internalistically authorize acts of law, and spontaneously to multiply the volume of law that it was able to generate. At a very early stage in the development of constitutions, rights became depositories of auto-constituent power within the political system.

In both of these respects, early constitutionalism formed a conceptual apparatus in which rights projected external legitimization for the political system, but in which, factually, the political system constructed itself internalistically around rights. Standing as a cipher for constituent power, rights enabled the running self-reflexive reproduction of the political system, and they enabled rapid and autonomously authorized structure-building processes through society. In fact, from the outset, rights formed an effective code for the political system. In the early constitutional state, the construction of the rightsrelevant/rights-irrelevant dichotomy became the essential basis for the reproduction and social transmission of political power. ${ }^{125}$

123. In the post-Founding United States, the growth of the federal judiciary, and thus the legal inclusion of the nation as a whole, was sustained by the use of rights norms to support legal rulings and processes of statutory review. See Jordan J. Paust, On Human Rights: The Use of Human Rights Precepts in U.S. History and the Right to an Effective Remedy in Domestic Courts, 10 Mich. J. INT'L. L. 572-74 (1989). At this time, proponents of national government saw nationhood as founded in the shared protection of rights. See Calvin H. Johnson, Righteous anger at The Wicked States. The Meaning Of The FOUNDERS' CONSTITUTION 8 (2005). These proponents of a strong national judicial and executive system used rights norms derived from early international law to expand and justify the political system. See Andrew Lenner, A Tale of Two Constitutions: Nationalism in the Federalist Era, 40 AMER. J. LEGAL HISTORY 73, 75 (1996). One historian states that, in the formulation of early doctrine and practice in revolutionary America, the "fundamental premise" of judicial review resided in the "ultimate sovereignty of the people." See William R. CASTo, The Supreme Court In The Early Republic: The ChiEF JUSTICESHIPS OF JOHN JAY AND OLIVER ELLSWORTH 232 (1995).

124. For analysis of Madison's view of the direct relation between the sovereign constituent will and the functions of courts reviewing parliamentary legislation, see Saikrishna B. Prakash \& John C. Yoo, The Origins of Judicial Review 70 U. CHI. L. REv. $946(2000)$.

125. That is, the use of rights within the political system made it possible both to legitimate power across society but to insulate the political system against unmanageable inclusion-rights were the precondition of politics, in the modern sense of the word. Tellingly, in fact, one historian describes eighteenth-century (pre-constitutional) France in 
The role of rights in promoting the internal abstraction of the political system assumed clear and manifest shape in the extended wake of most classical processes of constitution making in the later Enlightenment. After the initial explosion of constituent fervor in the later eighteenth century, it became evident in most post-revolutionary societies that the centration of modern political systems around an external constituent people was not sustainable, and claims for the foundation of the political system in external (constituent) power soon diminished. ${ }^{126}$ Indeed, constitutions quickly assumed the specific function of enabling political systems to dispense with external reference, and they distilled a formal paradoxical premise for the normative autonomy and internalism of the political system. This occurred through two separate constitutional trajectories (discussed below), both of which followed classical moments of revolutionary constitutional formation. The internalization of constituent power in the political system by rights played a vital role in both of these trajectories.

In some cases, notably in continental Europe, the proto-democratic impetus of constitutionalism in the French revolution was rapidly weakened: by 1795 this impulse was palpably flagging (although it extended still, in attenuated form, to Cadiz in 1812 and Norway in 1814, and it reasserted itself more widely in 1848). ${ }^{127}$ After this juncture, the political system was in most cases consolidated around a minimal constitutional order, and legislation was authorized through society by reference to social actors, not as agents participating in public will formation, but rather as bearers of limited private and civil (not primarily political) rights. ${ }^{128}$ In this respect, as Marx intuited, European constitutionalism in the nineteenth century was never definitively distinguishable from Bonapartism. ${ }^{129}$ In other cases, notably in the United States, the proto-democratic impetus of revolutionary foundation, although it did not disappear, also soon lost some of its

the following simple terms: "politics in the modern sense of the word did not exist." See Michael SONENSher, Work AND Wages. Natural LaW, Politics AND The EightEENTH-CENTURY FRENCH TRADES 46 (1989).

126. With a small number of exceptions, after 1795 few constitutions drew primary legitimacy from constituent power, and this principle all but disappeared as a source of legal authority.

127. The Spanish Constitution of 1812 was based in national sovereignty (Art 3). The Norwegian Constitution of 1814 still contained far-reaching provision for democratic legislation $(\S 49)$.

128. This re-orientation is expressed in exemplary fashion in BENJAMIN CONSTANT, ÉCRITS POLITIQUES [POLITICAL WRITINGS] 589-619 (1997) (1819) (Fr.).

129. See generally Karl MarX, Der AChTZehnTE Brumaire Des louis Napoleon [The EightEENTH BRUMAIRE of LoUIS NAPOLEON] (Dietz Verlag, 1960) (1852) (Ger.) (making use of the historical as a basis for further development of his theories, analyzing social class war). 
potency. ${ }^{130}$ In this setting, however, the idea of external democratic formation of the political system was replaced by a court-led system of legitimization and socio-political integration, in which law courts applying rights (notably rights in property) assumed primary responsibility for transmitting legislation, building political structures, and expanding the political system's cohesive form and its inclusionary hold on society at large. ${ }^{131}$

In both lines of post-revolutionary polity building, the fact that the constitution internalized an account of its constituent authority in the form of rights (stored either in private or civil law, or in the jurisdiction of courts) was the most important mainspring for the ongoing reproduction and stabilization of the political system. The establishment of normative order across society was driven, at the most fundamental level, by the systemic internalism of rights. Rights formed institutions that allowed both the legal system and the political system to operate as parts of a fully autonomous domain in society, the basis of whose self-reproduction was always stored within the system itself. ${ }^{132}$

At one level, in the evolution of the modern political system, rights formed a vocabulary in which different social exchanges could explain

130. In the American Founding, the commitment to full democracy was always limited, and in the Federalist Papers a clear distinction was made between Republic and a democracy. James Madison also spelled out a theory of constituent power, dividing the organs of government from the will of the people, that had the effect of transferring power to the courts. See FEDERALIST No. 53. The first decade of the new Republic witnessed an expansion of the legal apparatus, which was increasingly formalized and structured through reference to rights expectations, as a means of national consolidation. Famously, judicial expansion was treated with great skepticism by more democratically minded actors in the early Republic, for instance Thomas Jefferson. For one account of this vast subject see Justin Crowe, Building The Judiciary. LaW, Courts, ANd The Politics OF INSTITUTIONAL DEVELOPMENT 59 (2012).

131. See Stephen Skowronek, Building a New American STate: The Expansion OF NATIONAL ADMINISTRATIVE CAPACITIES 1877-1920, at 23, 25, 27, 28 (1982). For an alternative perspective on the system-building power of courts see Larry Kramer, The Lawmaking Power of the Federal Courts, 12 PACE L. REV. 270, 272 (1992). This role of courts was reinforced in the later twentieth century. See JONATHAN D. CASPER, LAWYERS Before The WarRen CoURT: CIVIL LiberTies AND CIVIL RIGHTS, 1957-66, at 39 (1972). On this general function of rights in promoting legal unity within the legal/political system see Christian STARCK, VERFASSUngen. ENTSTEHUNG, AUSLEGUnG, WirKungen und Sicherung [CONSTITUTIONS. CREation, INTERPRETATION, EFFECTS aNd SECURITY] 124 (2003) (Ger.).

132. On the correlation between rights and the differentiation of law and politics see again LUHMANN, supra note 106, at 185; Niklas Luhmann, Staat und Politik. Zur Semantik der Selbstbeschreibung politischer Systeme, Politische Vierteljahresschrift, Sonderheft 15: Politische Theoriengeschichte. Probleme einer Teildisziplin der Politischen Wissensschaft 112 (1984). 
their relevance to, and demand inclusion, in the political system. ${ }^{133}$ In so doing, rights allowed the political system selectively to distribute its power through society, to weaken alternative sources of power, and gradually to suffuse society with generalized reserves of political power. ${ }^{134}$ Yet, at the same time, rights ensured that most societal exchanges obtained a structure in which their factually intensified and collectively resonant inclusion in the political system was restricted. ${ }^{135}$

133. In classical constitutionalism, we can observe that rights were drawn from a pre-formed social register, and they acted to transpose interests in society which were already well consolidated (e.g., rights of conscience, rights of free movement, free labor, contractual liberty, and, above all, property) into a positively founding political vocabulary. For historical background, explaining how vital rights cemented in revolutionary American constitutionalism were initially cemented in Britain, see for example P.S. ATIYAH, THE RISE AND FALL OF FREEDOM OF CONTRACT 85-90 (1979); Louis Jaffe, The Right to Judicial Review I, 71 HARV. L. REV, 417 (1958). For my discussion of the state-building function of rights see, throughout CHRIS THORNHILL, A SOCIOLOGY OF CONSTITUTIONS: CONSTITUTIONS AND STATE LEGITIMACY IN HISTORICAL-SOCIOLOGICAL PERSPECTIVE (2011). On rights formulated in England as formative of the basic grammar of constitutionalism in the early revolutionary United States see John Philip Reid, In an Inherited Way: English Constitutional Rights, The Stamp Act Debates, and the Coming of the American Revolution 49 S. CAL L. REV. 1123 (1976); A.E. Dick Howard, Rights in Passage: English Liberties in Early America in THE BILl OF RIGHTS AND THE STATES. THE Colonial AND Revolutionary Origins Of American Liberties 4, 5, 10 (Patrick T. Conley \& John P. Kaminsky, eds, 1992).

134. The formation of the United States as a conclusively national society can easily be seen as a process in which rights gradually-albeit with dramatic lapses-saturated society and brought all persons and exchanges under even and equal control. The époques of most accelerated nation building and state consolidation (foundation, Reconstruction, Civil Rights movement) all witnessed the implementation of rights by federal courts as institutions for eliminating private power and consolidating society as a uniform legal arena. On the later stages of this process, see MICHAEL J. KLARMAN, From JiM CROW TO

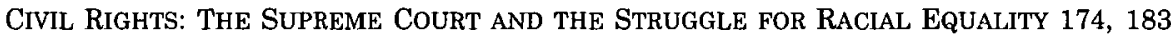
(2004). The extent to which this argument can be applied to Reconstruction is of course controversial; the claim that in the 1870s the Supreme Court performed an "emasculation of national civil rights enforcement authority" is still typical. ROBERT J. KACZOROWSKI, THE POLITICS OF JUdicial INTERPRETATION: THE FEDERAL COURTS, DEPARTMENT OF JUSTICE, AND CIVIL RIGHTS, 1866-1876, at 179 (2005). Yet for alternative views, see PAMELA BRANDWEIN, RETHINKING THE JUDICIAL SETTLLMENT OF RECONSTRUCTION (2011); Michael Les Benedict, Preserving Federalism: Reconstruction and the Waite Court, 1978 SUP. CT. REV. 39, 39, 40, 63 (1978).

135. In America during the Founding, by way of illustration, rights were clearly used restrictively to define the conditions under which single persons could obtain access to, or participate in, the political system. Even in the earliest state constitutions, the growing emphasis on singular rights reflected a skepticism towards fully inclusionary Republican legislatures. See, for example, the analysis of the Constitution of Vermont (1777) in William Michael Treanor, The Origins and Original Significance of the Just Compensation Clause of the Fifth Amendment, 94 YALE L.J. 701 (1985). On the general relation between rights-based judicial review and scepticism about the power of legislatures during the 
Rights dictated the conditions under which exchanges needed to be politicized, and they ensured that most social exchanges did not speak in an eminently political voice. ${ }^{136}$ To this degree, rights performed classical self-limiting functions for the political system. Rights thus developed as constructs that policed both the inclusivity and the exclusivity of the political system, and they facilitated the autonomous and functionally specialized distribution of law and power across widening and increasingly acentric societies. Although classical constitutions explained and legitimized their authority through reference to constituent power, it was the fact that the political system distilled constituent power internalistically, in rights, that proved the abiding functional legacy of classical constitutionalism. This was fundamental to the emergence of the legal/political system as a differentiated, relatively autonomous arena of exchange, able reliably to perform its functions in respect of adaptive law production.

It is notable in these respects that the original formation of constitutions coincided with a dramatic geographical extension and decentration of modern society, and constitutions assumed great importance in allowing societies to politically adapt to such conditions. ${ }^{137}$ Early constitutions enabled societies to react to their growing scale and complexity by formally abstracting a legal/political order, in which norms could be transplanted and reproduced across rapidly widening social horizons, and in which the recurrent requirement for an external underwriting of law and political power through particular decisions, interests, or acts of concrete participation could be rendered unnecessary. ${ }^{138}$ Moreover, the drafting of early constitutions coincided with an accelerated differentiation of society, meaning that legal and political actors were required to articulate their functions and generate an increasing volume of legislation at a high level of inner contingency and insulation: constitutions provided

Founding see Jack N. Rakove, The Origins of Judicial Review: A Plea for New Contexts, 49 STAN. L. REV. 1054, 1060 (1997).

136. For theoretical background, see LUHMANN, supra note 106.

137. Clearly, in both France and the United States, classical constitution writing coincided closely with the formation of societies as nations, and thus with the extension of socio-political order beyond personal and local power structures. On the relation between nationalism and central institution building see WILLIAM P. MURPHY, THE TRIUMPH OF Nationalism: State Sovereignty, The Founding Fathers, And The Making Of The CONSTITUTION 18 (1967).

138. One commentator observes incisively on the way in which rights-based review made it possible for the political to distinguish between "democracy and something we might (stipulatively) call popular sovereignty," and to define its legitimacy through the latter term. See Robert C. Post, Democracy, Popular Sovereignty, and Judicial Review, 86 CALIF. L. REV. 437 (1998). 
internally hardened formulae to stabilize these exchanges across pluralistic and increasingly complex social environments. 139

For both reasons, classical constitutions and the rights that they contained made it possible for society as a whole, in its increasingly complex form, to accept the palpably evident impossibility of its centration around localities, persons, and volitional decisions (either singular or collective). Rights-based constitutionalism also allowed society to use law and power as disembedded, pluralistically reproducible media of exchange. At a founding sociological level, therefore, early national constitutions and the rights that they contained expressly enabled emergent modern societies to distill legal and political resources into a form that could be effectively utilized across complex social terrains. ${ }^{140}$ In particular, constitutions allowed modern society originally to compensate for the fact that, owing to its inner contingency and progressively differentiated pluralism, it could not constantly muster specific external authority for its legal and political activities, and through the formation of constitutional law the modern political system managed to construct a set of principles able both to sustain its inclusivity yet also to reduce its reliance on external support. In organizing its politics around constitutions, society was able to presuppose law and power as stable resources despite the acentricity of its overarching structure, and even to insulate law and power against disruptions from its highly contingent environments. Society preserved itself against its own growing complexity through the internalistic normative order generated by constitutions and constitutional rights. As the basic code of the emergent political system, reference to rights (as depositories of constituent power) had the vital sociological significance of allowing society to construct, to internally extend, and to recursively reproduce autonomous structures of legal/political inclusion.

If classical constitutions are subject to functionalist reconstruction in this manner, it appears that many aspects of the diagnosis of an epochal change or deep caesura in the constitutionality of contemporary global or transnational society are based in a rather simplified literalistic view of classical constitutions. In fact, on the account given above, the internalistic and auto-constituent form of the contemporary transnational constitution extends the submerged functional substance of classical national constitutions. Above all, the abstracted autonomy and the self-referentiality of the contemporary legal apparatus are functionally extracted from the classical pattern of constitutionalism. In the constitutional order of contemporary society, the original function of

139. See my general discussion in THORNHILL, supra note 133.

140. Id. 
constitutional rights in intensifying the inclusivity of the legal and political system as distinct from physically localized constituent power and in enabling contingent legal and political inclusion of changing social objects reaches a point where the law is able, to a large degree, to autonomously reproduce and authenticate itself and to spontaneously generate multiple inclusionary norms from a location inside its internal apparatus. The reduction in importance of constituent power discussed above, in consequence, does not reflect a weakening in the substance of classical democracy: it reflects a broader sociological process, in which the political system has learned to translate its legitimacy from an external location (constituent power) into an internal location (rights) in order to maximize its autonomy and adaptability. This makes it possible for a political system to evolve which is no longer centered solely around sovereign authority, yet which nonetheless generates and disseminates political authority in reasonably coherent, explicable fashion. In the contemporary constitution, therefore, rights retain and intensify their residual function as the form of abstraction for political power. They continue to operate as institutions generating fluid reserves of political power, and they remain the decisive source of inclusionary cohesion for even the most pluralistic and multi-environmental societies. ${ }^{141}$ The self-referential authorization of law and power through rights, in fact, is the enduring principle by which contemporary society, in its differentiated pluralism, organizes its inclusionary operations: exchanges are integrated into society's diffuse legal/political systems through their reference to rights, and rights allow the law to build temporary political structures and to assume some degree of inner consistency in regulating even the most scattered and seemingly disconnected phenomena. In the emergent constitutional system of transnational society, constituent sovereign power is, to a large degree, ceded to rights. Rights act, self-generatively, as the primary force of institutional construction and legal/political inclusion. But in this respect, the contemporary constitution serves, not to contradict, but in fact to intensify, the functional logic of classical constitutionalism.

In this analysis, to be sure, it needs to be clear that, even if examined from a functionalist standpoint, there are undeniably aspects of the emergent contemporary constitution that possess a clear distinction against classical constitutions.

For example, we can identify a clear novelty in contemporary constitutionalism in the fact that the application of rights now habitually extends beyond the legal/political system in the classical

141. For overlapping comment see CHRISTLAN SEILER, DER SOUVERÄNE VERFASSUngsstaAT ZWISCHEN DEMOKRATISCHER RÜCKBINDUNG UND ÜBERSTAATLICHER EINBINDUNG 229 (2005). 
sense of the word. As discussed, this is evident in the fact that a governance system is emerging in which strict lines between private and public law have become fluid, and both regulatory and effective lawmaking functions are widely assigned to originally private actors. ${ }^{142}$ As a result of this, political institutions acquire intensified capacities for rapid structural formation, and they respond to requirements for legislation in a hyper-sensitively adaptive manner. ${ }^{143}$ This is made possible, to a large degree, by the fact that legal and political functions are typically overwritten with a highline rights code: that is, that legal and political functions are defined, and separate themselves from other functions, through reference to rights. Under the sanction of this code, political objectives can be fluidly allocated to a variety of institutions, and various organizations can assume constituted status as distinctively public or political. Rights thus construct a number of actors and organization as political. In this respect, rights clearly widen the contemporary system beyond conventional constitutional limits, and they enable the conduct of political functions by actors within a fluidly extensible political periphery.

In addition to this, one distinctive feature of the constitutionality of contemporary society is that rights formulate normative orders for social exchanges in a sectorally or functionally specific, nationally cross-cutting fashion. Indeed, at the very center of the concept of the transnational societal constitution is the principle of functional auto-constitutionality: that is, namely, that one functional domain can autonomously generate a normative apparatus for its exchanges, and these exchanges stabilize themselves as normatively independent of conventionally centered resources of the legal and political system. ${ }^{144}$ In this respect, we can observe that the capacities for auto-constituent organization of social exchanges always implied in constitutionalism have migrated beyond the determinate confines of the political system, and they regulate exchanges not conventionally classified as political.

142. A Constitutional Framework for Private Governance, supra note 90, at 219, 233. Generally, rather than simply following the increasingly common suggestion that private bodies and state actors have experienced an amalgamation, it seems more sociologically useful to observe ways in which societies distinguish some exchanges as specifically public. For an extreme version of the amalgamation thesis, see Larry Catá Backer, Private Actors and Public Governance Beyond the State: The Multinational Corporation, the Financial Stability Board and the Global Governance Order, 18 IND. J. GLOBAL LEGAL STUD. 751, 757 (2011).

143. As discussed above, the modern political system is able to generate laws at many levels, and it can incorporate many diverse actors within the lawmaking apparatus.

144. This is Gunther Teubner's contribution. See FISCHER-LESCANo \& TEUBNER, supra note 3; Teubner, supra note 93; Teubner, supra note 94. 
On the basis of the functional analysis of rights proposed in this article, however, we are inclined to retreat before declaring that even these more unprecedented or hyper-contingent aspects of the nascent transnational constitution form a wholly sui-generis dimension of contemporary constitutional law. On one hand, the fact that rights stimulate the emergence of new patterns of private/public governance preserves a continuum with the political dynamic of classical constitutions. In such processes, law's internal reference to rights increasingly creates a normative apparatus in which private actors can be securely co-opted into the periphery of state power, and state power can be devolved to private agencies. Nonetheless, the reference to rights also means that the conduct of public functions by private bodies can be subject to judicial control and placed within a politically regulated, even distinctively public-legal, framework. ${ }^{145}$ As a result of this, private bodies are assimilated into the extended periphery of statehood, and responsibilities traditionally assigned to designated legislatures and public office holders can be conducted in a much more flexible, positively reactive fashion. Rather than reflecting an erosion of classical constitutional principles, this accentuates the capacity of classical constitutions for generating rapid and unfounded structures of political inclusion. On the other hand, the relatively spontaneous generation of norms in different functional sectors of society also articulates more pronouncedly the internal logic of classical constitutionalism. Law's internal reference to rights enables different spheres of functional exchange to elaborate an inner legal/normative structure, so that transnational legal exchanges (in medicine, sport, media) can be conducted and regulated in reasonably predictable fashion, even where locally centered political authority is weak. In this respect, the primary impulse of society's emergent constitutionality is to extend the functions of classical constitutions, and to utilize rights to promote abstracted,

145. See Benedict Kingsbury, Nico Krisch \& Richard B. Stewart, The Emergence of Global Administrative Law, 68 LAW \& CONTEMP. PROBS. 15, 30, 33 (2004). Also on the role of courts in integrating private governance bodies into the state structure, see Joanne Scott \& Susan Sturm, Courts as Catalysts: Re-Thinking the Judicial Role in New Governance, 13 CoLUM. J. EUR. L. 565, 576 (2006). For a point that is similar to mine, see Anne Peters, Privatisierung, Globalisierung und die Resistenz des "Verfassungsstaates" [Privatization, Globalization and the Resistance of the "Constitutional State'], in STAAT UND VERFASSUNGSTHEORIE IM SPANNUNGSFELD DER DISZIPLINEN [STATE AND CONSTTTUTIONAL THEORY IN THE TENSION BETWEEN THE Disciplines] 128, 149 (Philippe Mastronardi \& Dennis Taubert eds., 2006) (Ger.). On the preservation of "meta-rules" in global private law despite extreme legal fragmentation, see the outstanding analysis in Moritz Renner, ZWINGENDES Transnationales REcht. ZUR STRUKTUR DER WIRTSCHAFTSVERFASSUNG JENSEITS DES STAATES [On the Structure of the Economic Constitution Beyond the State], 220 (2011). 
counter-factually sustained inclusion. ${ }^{146}$ In both respects, rights provide a register in which society can politicize itself (i.e. obtain consistent structures for the transmission and reproduction of power), and rights intensify their original function in enabling political inclusion in the absence of any specific will, decision, or external norm. In each case, rights play a vital role in modern complex society by providing a set of running constitutional norms, which are able to create a matrix for the constitution of semi-political and notably public-legal order in a rapid yet consistent fashion and against extremely contingent and rapidly extensible environments. ${ }^{147}$ As such, transnational rights reflect a deep connection with the original functions of constitutions, and their original capacity for constructing an improbable and autonomous basis for political power is clearly re-expressed.

In sum, we can suggest that the progressive formation of a transnational constitutional order, shaped by the rising autonomy and the pluralistic internality of rights, in many ways re-articulates the sociological functions always inherent in the design of constitutional democracy. We might identify those aspects of contemporary constitutionality that deviate most obviously from classical constitutionalism as replicating the functions of classical constitutions in that they create an internally reproducible normative order, which, from within itself, builds political structures across society and creates improbable normative orders against highly variable and contingent societal backgrounds. Above all, we might suggest that contemporary constitutionality is marked by a proliferation of the original function of rights in distilling constituent power as an inner element of the political system. As in classical constitutionalism, rights police the boundaries of inclusion and exclusion in the political system, and in doing this, they fulfill their deepest function as institutions enabling the self-reproductive and autonomous extension of consistent political structures across society. If rights originally articulated the irreducible premise for the autonomy of the political system, this premise has now wandered beyond institutionally-centric political systems. However, its basic function in creating contingent political structures for society remains unchanged.

146. By this, I mean that classical constitutions, based in constituent power, extended patterns of legal inclusion across expanding national societies. Rights-based constitutions now retain this function, albeit in societies marked by far more contingent and uncentered inclusionary processes and requirements.

147. On the creation of a flexibly extensible transnational legal culture through rights, see Nils Christian IPSEN, PRIVATE NoRmordnung Als Transnationales Recht? [Private Norm Orders As Transnational Law] 29 (2009) (Ger.). 


\section{CONCLUSION}

At many different levels, we can concur with more established analyses of contemporary supra- or transnational constitutionalism in their claim that the abstracted autonomy of rights, the transfer of competence from legislatures to unelected actors, the diffusion of democratic power, and the resultant rise in the judicialization of politics are processes which, in quasi-revolutionary fashion, redefine the legal order of modern society. In particular, courts acquire structural centrality in the system of contemporary global governance, and through their extended functions they form and reproduce the basic fabric of a highly acentric transnational constitution. As discussed, even beneath the clearly determined political arena, extended judicial functions currently exert a high degree of inner-sectorial constitutional force. In consequence, if the original model of constitutional democracy at the center of Western societies relied on a balance between democratic sovereignty and the establishment of rights as autonomous institutes, the tendency towards the autonomous construction of rights is now well advanced and apparently unstoppable. This appears to corroborate the view that the constitutional fabric of modern society differs paradigmatically from that cast by the rights revolutions that instituted the original political form of modern Western society. This also gives substance to the widening perception that the transnational rights revolution and the growth of a transnational constitutional order in contemporary society marks the end of the democratic constitutional tradition initiated in the Enlightenment and cemented in the twentieth century. 148 The prepotence of rights as dominant elements of the transnational political order reflects and reinforces the increasing autonomy of law, and it is a specific feature of societies marked by decreasing powers of centralized agency and a weakly-centered demos.

Despite this, however, the perception of this emergent reality of global constitutional governance as constituting a distinctively problematic occurrence or as marking a deep transformation of the original idea of constitutional democracy depends in certain respects on a literal/normative, and sociologically under-reflected, account of classical constitutional-democratic foundation. In particular, as discussed, this view relies on the literalistic presumption that modern states originally evolved around constitutionally organized reserves of participatory will formation. This view identifies rights merely as generalized normative limits on the unboundaried expressions of this will. However, if the historical/functionalist approach to constitutional

148. Dieter Grimm, Die ZuKunft Der Verfassung 12 (1991). 
rule proposed above is utilized, constitutional democracy might be observed, not in the first instance as a volitional construction, but rather as a form of internal/abstractive inclusion for the increasingly differentiated political and legal system of modern society. ${ }^{149}$ As such, constitutional democracy originally enabled legal/political institutions to integrate the social exchanges of members of a differentiated society in a reasonably even, positive, and internally reproducible fashion; to render a society subject to uniform, internally stabilized, and simply extensible normative expectation; and to establish the basic building blocks for the use of political power as an abstract, flexible, and positively circulated resource. ${ }^{150}$ In this model, rights necessarily gave impetus to the abstraction of political power, and throughout the construction of the modern political system, rights have performed the specific function of distilling both power and law into a form of intensely iterable autonomy and inclusivity. They allow the law and politics of society to internally adapt to, and assume complex cohesion in face of, the complex and contingent pressures of differentiated political inclusion that accompany the development of modern societal form. If constitutional democracy is seen as a pattern of evenly abstracted legal and political inclusion, rights and power are inextricably interdependent: the capacity of rights for producing reserves of power for modern society is the perennially defining feature of constitutionalism. In contemporary society, rights preserve and in fact intensify this primary function. It is a mistake to look for constituent power as the dominant force in the generation of democratic power. In both classical and contemporary constitutionalism, this function falls to rights.

As a more general observation, analysis of the emergent form(s) of the transnational constitution might benefit from more encompassing sociological examination. A perspective founded in a historical/functionalist approach might be able to offer an account of this constitution that provides a causal framework for interpreting its formation, proposes a generic sociological paradigm for approaching the intensified abstraction of rights, and elucidates the position of this constitution within a wider morphology of modern power. On this approach, the new models of highly judicialized, rights-led democracy implied in global governance regimes do not negate the original

149. See a similar account in Niklas Luhmann, Machtkreislauf und Recht in Demokratien, 2 ZEITSCHRIFT FÜR RECHTSSOZIOLOGIE, 164 (1981).

150. Note again the Luhmannian theoretical background to these claims. See generally Niklas Luhmann, Verfassung als Evolutionäre Errungenschaft [Constitution as an Evolutionary Accomplishment], 9 RECHTSHISTORISCHES JOURNAL [LEGAL-HISTORICAL JoURNAL] 201 (1991) (Ger.). 
normative form of constitutional democracy. On the contrary, they, transform, extend and perpetuate it. This rising pattern of global governance constructs a system of extensible legal and political inclusion in a societal reality in which the relatively controllable processes of territorially circumscribed integration characterizing earlier modern societies have become impossible, and where functions of legal and political inclusion need to be performed at a very high level of abstraction, internal contingency, and precarious variability. In this reality, rights necessarily assume a high level of distinction against any single or defined political will. In contemporary society, the capacity of the legal/political system to incorporate a stable and identifiable demos to support its inclusion is weak, and its reliance on the ability of rights to generate highly abstracted and internalized principles of inclusion is high: rights bring a support to law that enables it, in absence of external or volitional centration, to project from within itself an abstracted construction of its addressees, and, using this projection, to replicably perpetuate and legitimize its operations. The increasing abstraction of rights in contemporary society is thus a response to the rising demands for highly contingent inclusion presently confronting legal and political actors. Yet this also expresses an inclusionary dynamic defining all constitutional/democratic systems, and it specifically accentuates earlier sociological functions of constitutions in order to preserve a system of flexible political inclusion adequate to contemporary society.

In contemporary, transnationally interconnected societies, transnational rights have assumed the polity-building functions first accorded (perhaps too literalistically) to sovereign/democratic agents, and the functions of the demos in providing legitimacy for political power have been displaced into the functions of rights. Societies now use rights as an intensely dialectical model of inclusion, allowing their legal and political systems to internalize a construction of their constituent origins in order to preempt and to uniformly legitimize their political functions in relation to highly varied and pluralistically situated objects (persons) in societies shaped by weak reserves of agency. Against a background of rising societal contingency and extreme unevenness and uncertainty in the social terrains subject to legal/political inclusion, rights have necessarily assumed a more far-reaching role in pre-constructing the procedures and objects for legal inclusion. Rights now fully define these procedures and objects, such that the volitional element of democracy, weak in all democratic polities, is all but eradicated. Rights cement inclusionary legal and political realities in society by implanting in the law a movable and replicable image of its constituent authors, which was always implied as, yet never factually 
became, the author of law's force. ${ }^{151}$ Rights are the law's reduced and auto-constituent projection of its own constituent source, and, endlessly re-entered into the law by the law, they constitute the form of law's autonomy and inclusivity in its highly varied and unpredictable societal settings. As such, rights insulate the law against the growing contingency of its application. They project for law an internal normative source, or quasi-constituent structure no longer provided by any clear source of human agency, and they allow modern societies to create consistent political structures across diffuse environments.

As mentioned, in transnational society, rights have finally defined a code for the contemporary political system. That is, rights have the function of allowing a society to register certain exchanges as requiring legal inclusion, and, even in conditions of extreme polycentricity, they allow the formation of collective regulatory structures. Indeed, they enable societies to mark out certain exchanges and institutional procedures and actors as still distinctively political. This may be seen as anti-democratic. But it may also be seen as a sociological perpetuation of the inner functions of constitutional democracy, whose original, albeit functionally submerged, design also projected rights as the code of society's politics. As mentioned, the global constitutional form set by the transnational rights revolution is merely a rearticulated or intensified expression of the national constitutional form. However, most observers of transnational constitutions are prevented by their methodological apparatus from identifying and comprehending this idea.

151. For a similar point, see David Jacobson \& Galya Benarieh Ruffer, Courts Across Borders: The Implications of Judicial Agency for Human Rights and Democracy, 25 HUM. RTS. Q. 74, 83, 86, 90 (2003). 
